\title{
Tuko Pamoja: A guide for talking with young people about their reproductive health
}

KARHP

PATH

Population Council

Follow this and additional works at: https://knowledgecommons.popcouncil.org/departments_sbsr-rh How does access to this work benefit you? Let us know!

\section{Recommended Citation}

"Tuko Pamoja: A guide for talking with young people about their reproductive health." Nairobi: Program for Appropriate Technology in Health (PATH), 2005. 


\section{Tuko Pamoja}

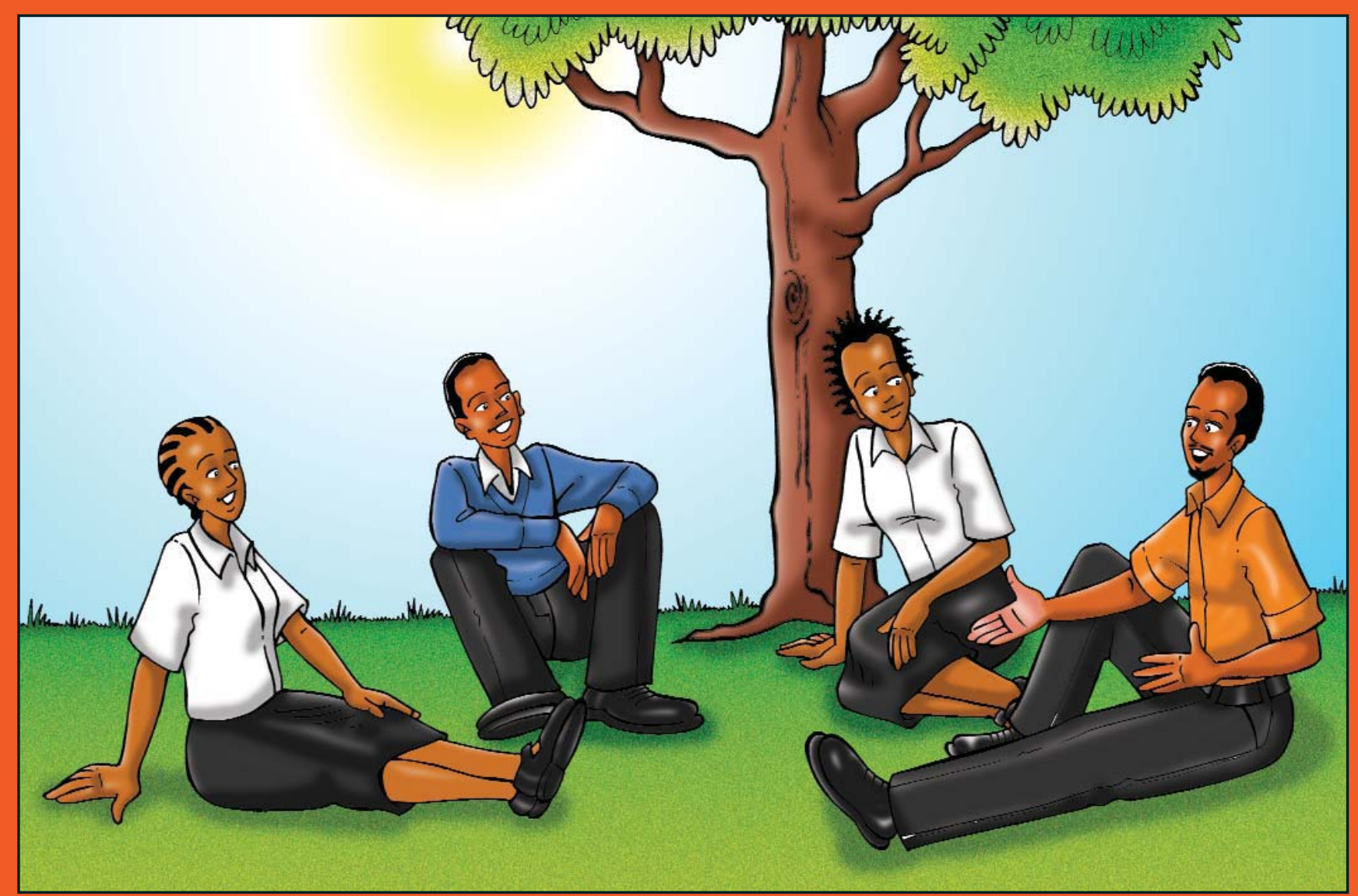

A Guide for Talking with Young People about their Reproductive Health 
A Guide for Talking with Young People about their Reproductive Health 


\section{Acknowledgements}

This document is part of the Kenya Adolescent Reproductive Health Project's (KARHP) Tuko Pamoja (We are Together) series. It is based on KARHP's Adolescent Reproductive Health and Life Skills Curriculum and draws from other adolescent reproductive health and youth-friendly publications including EngenderHealth's YouthFriendly Services: A Manual for Service Providers, FOCUS on Young Adults' Making Reproductive Health Services Youth Friendly, PATH's Life Planning Skills: A Curriculum for Young People in Africa and Pathfinder International's Reproductive Health Services for Adolescents: Comprehensive Reproductive Health and Family Planning Training Curriculum. Full references can be found in the reference section of this document.

This guide was developed by Stephanie Martin with input from Oluoch Madiang', Eva Muthuuri, Rikka Trangsrud and Jon Kaplan. Cover illustration by Eric Muturi-Kioi.

Funding for the development and production of this guide was provided to the Kenya Adolescent Reproductive Health Project (KARHP) through the President's Emergency Plan for AIDS Relief and the Office of Population of the United States Agency for International Development. The opinions expressed herein are those of the authors and do not necessarily reflect the views of USAID.

Copyright (C 2005, Program for Appropriate Technology in Health (PATH). All rights reserved. Any part of this manual may be photocopied or adapted without permission, provided that the parts copied are distributed free or at cost (not for profit) and that credit is given to KARHP, PATH and Population Council.

\section{November 2005}

\section{PATH}

ACS Plaza, $4^{\text {th }}$ Floor, Lenana Road

P.0. Box 76634-00508

Nairobi, Kenya

Tel: 254-20-3877177

\section{Population Council}

General Accident Insurance House

Ralph Bunche Road

P.0. Box 17643

Nairobi, Kenya

Tel: 254-20-2713480 


\section{Contents}

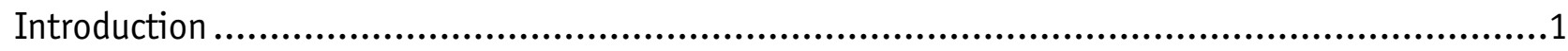

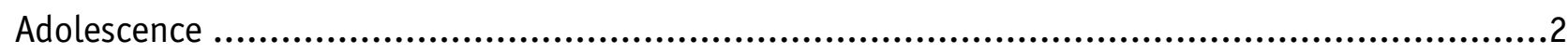

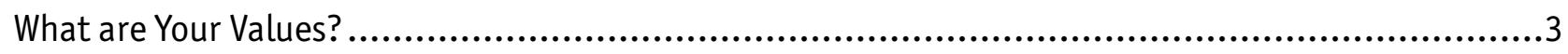

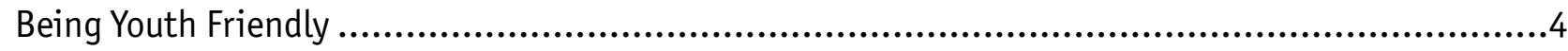

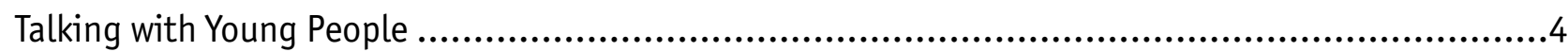

Talking about Sexuality with Young People..................................................................5

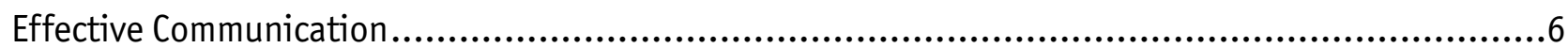

Facilitating a Group Discussion .....................................................................

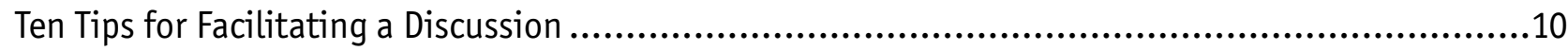

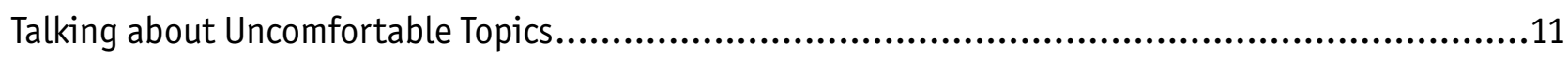

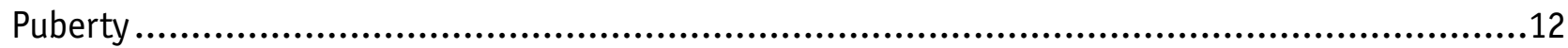

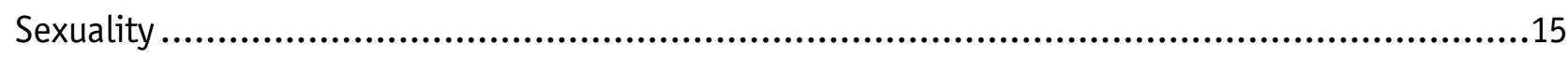

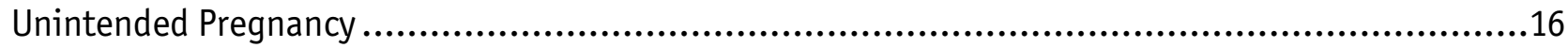

Unsafe Abortion .............................................................................................16

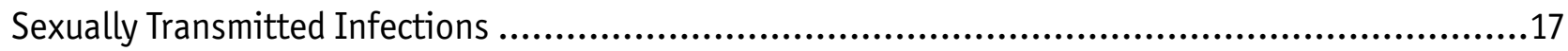

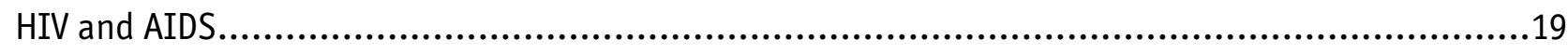

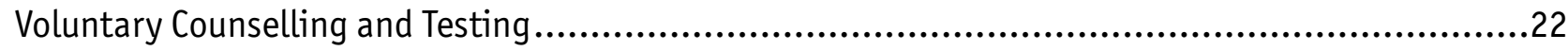

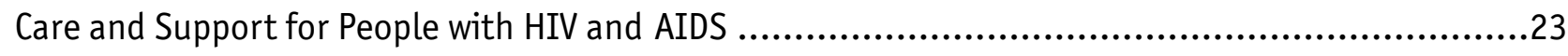

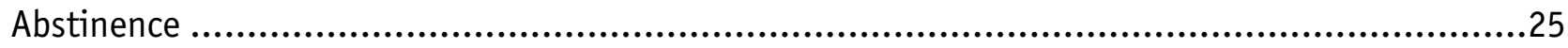

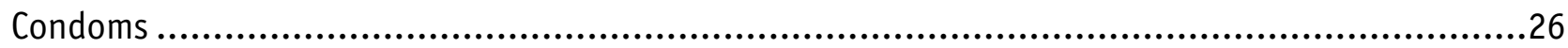

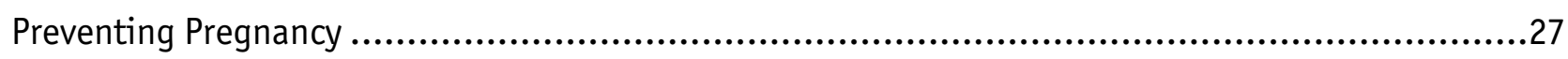

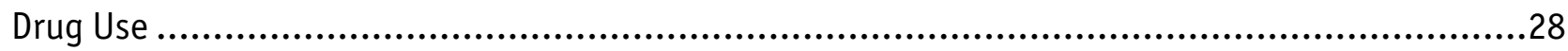

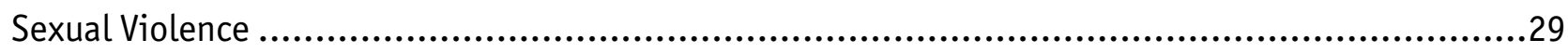

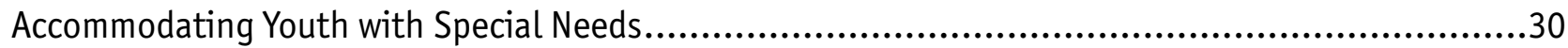

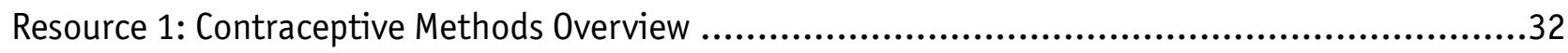

Resource 2: How to use a Male Condom ....................................................................34

Resource 3: How to use a Female Condom ................................................................35

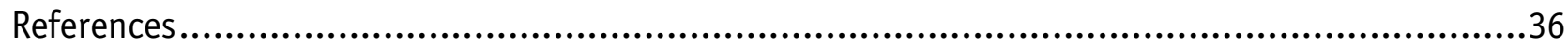




\section{The Facts}

\section{Sexually Transmitted Infections (STIs)}

Young people have much higher rates of STIs than adults for both biological and behavioural reasons.

Young people's immature immune and reproductive systems make them vulnerable to STIs.

Young people aged 15-24 account for half of all new HIV infections in Kenya.

Infection with an STI increases the risk of becoming infected with HIV.

\section{Adolescent pregnancy}

By age 19, almost half of adolescents in Kenya have begun childbearing.

The risk of maternal death among pregnant women ages 15-19 is four times higher than the risk among women ages 25-29.

Adolescent births are more likely to result in low birth weight, premature births, stillbirths, and neonatal deaths.

Ten thousand girls drop out of school every year in Kenya because of pregnancy.

\section{Contraceptive use}

Few married young people use contraception.

Young people often do not plan to have sex and do not have contraceptives with them.

Young people lack information and knowledge about contraceptives.

\section{Reproductive health risks faced by adolescents}

Young people take higher risks in general, including unprotected sex.

Young women are less able to resist sexual pressure and coercion.

Young people in disadvantaged situations are vulnerable to sexual exploitation.

Young women are disproportionately represented among abortion-seekers.

Sources: Central Bureau of Statistics (CBS) [Kenya], Ministry of Health (MOH) [Kenya], and ORC Macro. Kenya Demographic and Health Survey 2003. Calverton, Maryland: CBS, MOH, and ORC Macro; 2004. MOH Division of Reproductive Health. National guidelines for provision of youth friendly services in Kenya. Nairobi: 2005. EngenderHealth. Youth Friendly Services: A Manual for Service Providers. [Draft] New York: 2002. PATH, Population Council. Tuko Pamoja: Adolescent Reproductive Health and Life Skills Curriculum. Nairobi: PATH; 2005. 


\section{Introduction}

Adolescence is the time of transition between childhood and adulthood. During this time, young people experience many physical, emotional and social changes. Physical changes, such as menstruation in girls or development of facial hair in boys, can be confusing and worrisome for adolescents. During adolescence, young people develop new interests and attempt to establish their independence from adults. Peer pressure increases and can become particularly difficult for young people to resist. Providing young people with support by talking with and listening to them as well as ensuring they have access to accurate information can help them understand the wide range of changes they are experiencing, and make this transition period easier.

Unfortunately, many adolescents do not have access to the reproductive health information they need to make informed choices about their health and their futures. They may be embarrassed asking parents or other adults questions about sexual and reproductive health. Although parents, teachers, religious and community leaders, and health care providers are expected to educate adolescents about personal and physical development, relationships and their roles in society, it may be difficult for them to do so in a comfortable and unbiased way.

For these reasons, it is important to meet adolescents' need for information and services. This can help them resist peer pressure to become sexually active and protect themselves against unintended pregnancies and sexually transmitted infections, including HIV, if they decide to have sex. Young people have both the need and the right to access this type of information and services. Adolescent reproductive health education provides adolescents with information about reproductive physiology and puberty; protective behaviour, including abstinence and contraceptives; and the responsibilities and consequences that come with sexual activity.

\section{Importance of working with youth}

The social and developmental consequences of sexual and reproductive decisions are far-reaching. Health, education, interpersonal relationships and preparation for the world of work are closely linked. An unintended pregnancy can permanently change a young girl's life. It can be difficult for her to return to school and continue with the plans she had for her future. Becoming HIV positive can bring an end to a young person's prospects for a healthy and productive future.

Young people have a right to the information and services they need to make healthy decisions about their lives. Providing young people with accurate reproductive health information promotes sexual health and wellbeing. This includes supporting healthy, responsible and positive life experiences, as well as preventing disease and unintended pregnancy. Sexuality education is most meaningful and effective when it provides information, challenges myths, explores values, and develops skills.

Many believe that education on sexuality, reproduction, HIV and AIDS and safer sex will encourage adolescents to engage in sexual activity. In fact, this type of information generally leads to more responsible and safer attitudes towards sex and sexual relationships. Studies have shown no evidence that sexuality education leads to an increase in sexual activity; rather in many cases it leads to a delay in sexual initiation. Sexuality education provides knowledge about reproductive functions and processes, puberty and pregnancy and STI prevention. It emphasizes a broad approach to sexuality, focusing on a whole person and presenting sexuality as natural and a positive part of life. Telling the truth about sexuality could make it easier for young people to talk with parents, teachers, community and religious leaders and other influential adults.

\section{Audience}

This guide was developed for Public Health Technicians working with the Ministry of Health as part of the Kenya Adolescent Reproductive Health Project. However, it can be used by anyone wishing to broaden his or her understanding of adolescent reproductive health issues and improve his or her ability to communicate with young people. 


\section{Adolescence}

Adolescence is the period in life when an individual is no longer a child, but not yet an adult. It is a period of drastic physical and psychological changes, as well as changes in social expectations and perceptions. Physical growth and development are accompanied by sexual maturation often leading to intimate relationships. The individual's capacity for abstract and critical thought also develops along with a sense of selfawareness. Although adolescence is a phase and not a fixed time period, the following table can be used to better understand the timing of these changes.

\begin{tabular}{|c|c|c|c|}
\hline Category of change & Early $10-13$ years & Middle $14-16$ years & Late $17-19$ years \\
\hline Growth & $\begin{array}{l}\text { Secondary sexual charac- } \\
\text { teristics appear } \\
\text { Growth accelerates and } \\
\text { reaches peak }\end{array}$ & $\begin{array}{l}\text { Secondary sexual charac- } \\
\text { teristics advanced } \\
\text { Growth slows down } 95 \% \text { of } \\
\text { adult height attained }\end{array}$ & Physically mature \\
\hline Cognition & $\begin{array}{l}\text { Concrete thinking } \\
\text { Long-range implications of } \\
\text { actions not perceived } \\
\text { Thinking is more abstract }\end{array}$ & $\begin{array}{l}\text { Capable of long-range } \\
\text { thinking } \\
\text { Reverts to concrete think- } \\
\text { ing when stressed }\end{array}$ & $\begin{array}{l}\text { Able to think abstractly } \\
\text { Future-oriented } \\
\text { Understands long range } \\
\text { options }\end{array}$ \\
\hline Psychosocial & $\begin{array}{l}\text { Preoccupied with: } \\
\text { Rapid physical growth } \\
\text { Body image } \\
\text { Physcial changes }\end{array}$ & $\begin{array}{l}\text { Re-establishes body image } \\
\text { Preoccupation with fanta- } \\
\text { sy and idealism }\end{array}$ & $\begin{array}{l}\text { Feels invincible } \\
\text { Intellectual and functional } \\
\text { identity established }\end{array}$ \\
\hline Family & $\begin{array}{l}\text { Defining boundaries of } \\
\text { independence/ } \\
\text { dependence }\end{array}$ & Conflicts over control & $\begin{array}{l}\text { Child-parent relationship } \\
\text { changes to adult-adult } \\
\text { relationship }\end{array}$ \\
\hline Peer group & $\begin{array}{l}\text { Seeks affiliation to count- } \\
\text { er instability } \\
\text { Needs identification to } \\
\text { affirm self image }\end{array}$ & $\begin{array}{l}\text { Peer group defines behav- } \\
\text { ioural code }\end{array}$ & $\begin{array}{l}\text { Peer group less important } \\
\text { than individual friendships }\end{array}$ \\
\hline Sexuality & $\begin{array}{l}\text { Self exploration and eval- } \\
\text { uation }\end{array}$ & $\begin{array}{l}\text { Preoccupation with } \\
\text { romantic fantasy } \\
\text { Testing ability to attract } \\
\text { opposite sex }\end{array}$ & $\begin{array}{l}\text { Forms stable relationships } \\
\text { Mutuality and reciprocity } \\
\text { Plans for the future }\end{array}$ \\
\hline
\end{tabular}

Source: WHO. Orientation Programme on Adolescent Health for Health-care Providers. Geneva: 2003.

Remember that adolescents are not a homogenous group. Their needs vary based on their sex, stage of development, life circumstances and the socio-economic conditions of their environment. 


\section{What are Your Values?}

Read the following statements and after each one, think about whether you agree or disagree and why.

Condoms should be available to young people of any age. (agree/disagree)

Sex before marriage is acceptable. (agree/disagree)

Sexuality education can lead to early sex and promiscuity. (agree/disagree)

It is worse for an unmarried girl to have sex than for an unmarried boy. (agree/disagree)

Condoms are the best contraceptive for youth because they protect against STIs, including HIV. (agree/disagree)

Young people do not like to talk with adults about sexuality and reproductive health. (agree/disagree)

After reading the above statements, ask yourself the following questions:

How did it feel to agree or disagree with these statements?

Were any statements easier or harder to make a decision about?

How can our values and attitudes affect our ability to work with young people?

What strategies can you use when your values are different from those of young people?

How can your values support or hinder your work with young people?

What can you do to overcome values that hinder your work?

It is normal for people to have strong opinions about sexuality and reproductive health issues. It is important to be aware of your own values in order to try to be more accepting of different viewpoints. Young people will be more likely to talk honestly and openly about their own values, opinions, and experiences if they feel that they are being accepted and not judged. Keep in mind that your values and attitudes can sometimes affect your ability to work with young people. Be aware of your attitudes and feelings but do not expect young people to share them. What you think and feel will have a strong influence on how you respond to their questions. Try to be tolerant and accept that they may not share your values.

As you begin to talk with adolescents, you may find that you do not share the same values. You may want to encourage adolescents to delay sexual activity, but young people may already be sexually active. It is important to try not to let personal biases influence professional behaviour. You can play an important role by providing young people with factual information and supporting young people in making their own decisions for their future, based on their knowledge and reproductive goals.

Young people often ask influential adults about their own values related to sexuality and reproductive health. It is appropriate to share some of your personal values and to discuss the values that you learned from your family, especially those that helped you to make positive choices in your life. It is better not to share personal values related to highly controversial topics. If asked for your opinion on a controversial topic, say something like "I'm more interested in what you believe right now," or "Why do you want to know?" If you do share personal values, be clear that the values are right for you, but not necessarily right for them. 


\section{Being Youth Friendly}

Programs are youth friendly if they have qualities that attract young people, meet their needs and provide a comfortable and appropriate setting to serve them. Ideally, young people should be involved in the initial planning phase and continue to be involved throughout the program. Specifically, programs should:

Provide factual information on reproductive health and sexuality.

Respect values, decisions, and experiences of young people.

Maintain privacy and confidentiality.

Pay attention to the needs of young people.

Provide space and time for young people to talk and ask questions in a safe and comfortable environment.

To meet the needs of adolescents, consider ways to attract and better serve young people. Below are some strategies to make activities more youth friendly:

Involve young people in the design and implementation of programs and activities when appropriate.

Be aware that the needs and interests of youth are different from those of adults and plan accordingly.

Use locations where they already gather, rather than expecting them to come to you (youth centres, sporting events, or work sites, and informal gathering places like video dens, idling spots, maskanis, etc.).

Form linkages with other organizations that offer services to young people, including educational and social service programmes.

Stress that privacy and confidentiality will be maintained in your activities.

Develop referral systems. Find out about other services in your community for adolescents. Keep a list of these services readily available and share them with young people as needed.

Facilitate educational talks with young people on adolescent reproductive health topics.

Involve young people by creating a youth advisory board.

Train peer educators to provide information, education and referrals to young people.

Involve parents and other adults young people go to for advice and support.

\section{Talking with Young People}

Adolescents are going through dramatic biological and psychological changes and may not be comfortable talking about these changes and other issues related to their reproductive health. When young people feel comfortable and safe they are more likely to talk about issues related to their changing bodies and their reproductive health. It is important to interact with young people in a helpful, non-judgemental way in order to build a trusting relationship and rapport.

The more comfortable adolescents feel, the more likely they will be to speak openly about their concerns and ask questions that are important to them. When people feel safe they speak more freely, give honest answers, ask questions and learn more. Three ways to create a sense of comfort and safety are:

Respect: When talking with adolescents, treat them as people who are capable of making good decisions. Show that you accept their views, beliefs, values and experiences even if they are different from your own.

Privacy: When talking with adolescents it is important that it is in a place where they cannot be overheard and is free from interruptions.

Confidentiality: It is important for adolescents to know that their discussions with you will not be shared with others. If, in some circumstances, you believe it necessary to share information with others (for example, to prevent further sexual abuse), you should explain why it is important and with whom, when, and how you plan to share the information. 
To build trust and rapport:

Allow enough time for adolescents to become comfortable enough to ask questions and express their feelings and concerns.

Demonstrate an understanding of adolescents' concerns and experiences.

Show sincerity and a willingness to help.

Share your views about their needs and concerns without passing judgement.

Be honest. Admit if you do not know the answer to a particular question. Give them or yourself the task of researching the question and share the findings when you meet next.

\section{Talking about Sexuality with Young People}

Talking with adolescents about sexuality can be challenging because it is a sensitive topic. It is normal for young people to feel emotional, defensive, and uncomfortable talking about it.

Good communication about sexuality requires:

An environment that encourages adolescents to ask questions and discuss their concerns and needs.

Patience and understanding of the difficulty adolescents have in talking about sex.

Privacy and confidentiality.

Respect for young people's feelings, choices, and decisions.

Information that is honest and easy to understand.

Talking about feelings and relationships in addition to facts.

Discussions that analyse consequences as well as advantages and disadvantages of different options.

Assistance in making informed decisions and ways to put them into action.

When young people make decisions based on accurate and appropriate information, they feel a sense of satisfaction and feel capable of adopting healthy behaviours. Young people may have to face many difficult decisions, and the more factual information they have, as well as a supportive environment to discuss options, the easier it can be for them to make such decisions. The following are examples of the kinds of decisions young people may face:

How to discourage and prevent unwanted sexual advances.

Whether or not and when to engage in sexual relations.

How to prevent pregnancy and STIs, including HIV.

How to address sexual abuse or violence.

Whether or not and when to conceive a child.

What to do if they become pregnant unintentionally.

What kind of antenatal care to seek and where to go. 


\section{Effective Communication}

Communication is both verbal and nonverbal. Nonverbal communication can reinforce or contradict verbal communication. It is important to think about the different nonverbal and verbal behaviours you use when talking with young people. Sometimes, without realizing it, we communicate one message verbally, while communicating the opposite message nonverbally.

\section{Nonverbal communication}

Nonverbal communication is a combination of actions and behaviours that show how people feel about something at times without even realizing it. Nonverbal communication is especially important because it communicates the level of interest, attention, warmth and understanding we feel towards someone.

Positive nonverbal cues:

Eye contact without staring

Leaning forward when someone is talking

Smiling for warmth and encouragement

Nodding to show understanding and listening

Facial expressions that show interest and concern
Negative nonverbal cues:

Not making eye contact

Looking at your watch

Fidgeting or looking through papers or documents Frowning or other disapproving facial expression

Sitting with your arms crossed

Leaning back from the person talking

\section{Verbal communication}

The following techniques can improve verbal communication and build rapport with adolescents. These are appropriate for both one-on-one meetings as well as group talks.

Provide information in a simple, straightforward way. Avoid technical terms or difficult words.

Provide information based on what adolescents know or have heard.

Understand and use the words and expressions adolescents use to talk about their bodies, dating and sex. Do not give too much information at one time.

Use a tone of voice that expresses concern and interest.

Gently correct misconceptions.

Use materials and visual aids for reinforcement (if available).

\section{Create a good first impression}

Be on time. Show them that you value their time.

Smile and warmly greet them.

Introduce yourself and explain what you do.

Ask them to introduce themselves and what they like to be called.

\section{Establish rapport during the first session}

Face adolescents and sit in chairs of similar height or on the ground. In a group talk, sit in a circle.

Use adolescents' names during the session.

Show that you want to understand their thoughts, feelings and experiences and would like to help.

Congratulate them for wanting to learn more about their bodies and being healthy.

Acknowledge that it can be difficult and uncomfortable to talk about these issues. 


\section{Eliminate barriers to good communication}

Show respect for adolescents' beliefs, opinions, and differences.

Avoid making judgemental responses - both in verbal and non-verbal communication.

\section{Listen actively}

Show your sincere interest and understanding and give them your full attention.

Sit comfortably and try to avoid movements that could be distracting.

Give them time to think, ask questions, and speak.

Focus on what they are saying and not on what you plan to say next.

Periodically repeat what you have heard, confirming that everyone (including yourself) has understood.

Explain words or concepts that are unclear or need more explanation.

Try to think about what you would do if you were experiencing the same thing.

Summarize what has been said.

\section{Tips for talking with young people}

Accept them as they are, without passing judgment.

Respect their own unique qualities and potential.

Encourage their ability to make their own decisions.

Encourage them to take responsibility for their decisions.

Provide enough factual information to help them make decisions.

Avoid giving advice.

Help them evaluate their feelings about their problem or concern.

Provide them with emotional support. 


\section{Facilitating a Group Discussion}

Group discussions are important because they allow young people to share their experiences and learn from each other. Participation and dialogue are essential for effective group discussions. When you are facilitating a discussion, be sure to involve participants in the discussion and listen to them with interest and respect. The following tips can help to make group discussions effective and lively:

Thank participants when they contribute to the discussion or share their views or experiences. People need to feel that their comments and questions are valued.

Try to have as many different people participate in the discussion as possible. To encourage participation, say, "Is there anyone else who has something to share?" Never call on an individual directly as it can make him or her uncomfortable.

Listen closely when people are talking. Remember that it takes courage to speak in front of a group. Demonstrating to people that you are listening can help them feel more confident and comfortable speaking in front of the group. It can also give you a better understanding of someone's situation.

Use open-ended and follow-up questions to encourage participation. If a participant gives a short answer, try to encourage him or her to give more information by saying, "Can you tell us more about that?"

Do not interrupt people when they are speaking. If someone is talking for too long and you must interrupt them, be sure to apologize.

\section{Presenting information}

Review the information you plan to present before the session so that you are familiar with it.

Do not speak too quickly. Be sure they can hear you and understand what you are saying.

Do not speak too slowly or participants may lose interest or become bored.

Maintain eye contact as you present the information. Even if you have to read it, be sure to look up from time to time so that people do not feel they are being ignored.

After you make an important point, wait for a moment to let participants think about it.

Pay attention for signs of confusion and ask participants if they have questions.

\section{The art of asking questions}

The ability to ask meaningful questions that stimulate discussion, and are related to topics of a group discussion, is an important skill for a facilitator. Effective, stimulating questions are open-ended, engage participants and encourage participation.

A facilitator can ask questions in order to:

Ensure participants understand the information being discussed.

Clarify a point or reinforce essential points.

Stimulate participants to think more about a topic.

Encourage group participation and maintain interest and attention.

Draw relationships between facts and their application to participants' life.

The purpose of asking questions is not to interrogate. Questions are for the participants, and you should not answer the question even if there is some silence. Be patient and remain silent for at least 10-15 seconds; it is likely that someone will break the silence and try to answer the question.

Questions should encourage participants to think deeply, allow the group to make their own conclusions and encourage reflection so they can apply the information to their own lives. 
There are four types of questions:

1) Closed-ended questions can be answered by yes, no, a number or a few words. They can be used at the beginning of a conversation or discussion to break the ice, since they do not require the respondent to reveal sensitive information or to share feelings. An example is, "Do you think that it is normal to talk with your parents about sex?"

2) Open-ended questions have many possible answers. They can be used to learn about feelings, knowledge or beliefs. An example is, "How does your partner feel about condoms?" Asking questions that begin with "why" may be intimidating or seem judgemental. It is preferable to ask, "What are your reasons for...?"

3) Probing questions help clarify responses to open questions. An example is, "Can you tell me how your friend's experience has made you feel about abortion?"

4) Leading questions lead the respondent in a certain direction and are not desirable for facilitating discussions. An example is, "Isn't it normal for boys to have wet dreams?"

\section{Responding to participants' questions}

Participants should be encouraged to ask questions. Remember the tips below when responding to questions:

Allow the person to finish asking the question and do not rush to answer it.

Listen carefully to be sure you understand the question.

Do not answer too quickly. Take a moment to think about your answer.

Repeat the question (to be sure that you have understood it and that the group has heard it).

Thank the person asking the question.

Choose words carefully and think about how your response can affect an individual.

Never belittle or embarrass someone for asking a question.

If you do not know the answer, admit it. Promise to look for more information or ask if participants know.

Ask a participant, or the group as a whole, to respond to the question or to give their point of view. (Every time you respond directly to a question instead of letting the group reflect, you reduce participation and the opportunity for the individual or group to learn.)

Make an effort to give all participants an opportunity to talk.

\section{Responding to participants' responses}

There are four types of responses that you can expect when you ask participants a question:

Correct response: Repeat the participant's response to positively reinforce it and ensure that everyone heard it or ask the participant to repeat the response loudly enough for everyone to hear it.

Partially correct response: Compliment the participant for the correct part, and then reformulate the rest of the question to the same participant or someone else. Or ask, "Is there anyone who wants to add any other information?"

Incorrect response: Explain (in a constructive way) that the response is not quite correct and repeat the question to put the participants on the right track.

A response that adds an interesting but unanticipated idea: Thank the participant and recognize his or her idea. You can either discuss it at the time or let participants know that you will discuss it later. 


\section{Ten Tips for Facilitating a Discussion}

Your role during a group discussion is to facilitate the flow of comments and questions from participants. Although it is not necessary to make a comment after each participant speaks, periodically assisting the group with their contributions can be helpful. Here are ten tips that can help you when leading group discussions.

1. Paraphrase what a participant has said so that he or she feels understood, and that the other participants can hear a brief summary of what has been said.

"So, you're saying it's difficult to talk with your parents about sexuality."

2. Be sure you understand a participant's statement or ask the participant to clarify what he or she is saying.

“I'm not sure that I understand exactly what you meant. Could you please explain it to us again?"

3. Compliment an interesting or insightful comment.

“That's a good point. I'm glad that you brought it to our attention."

4. Add to a participant's comment with examples or suggest a new way to think about the problem.

“Your comments provide an interesting point from a young person's perspective. It could also be useful to think about how a parent would view the same situation."

5. Energize a discussion by quickening the pace, using humour or asking the group for more contributions.

“For the next two minutes, let's see how many ways you can think of to say 'no' to a partner who is pressuring you to have sex before you are ready."

6. Disagree (gently) with a participant's comments to stimulate further discussion.

"I understand your point, but I'm not sure that what you are describing is always the case. Has anyone else had an experience that is different from Maina's?"

7. Mediate differences of opinion between participants and relieve any tension.

"I can see that Margaret and Mary are not really disagreeing with each other but are just talking about two different sides of this issue."

8. Link ideas together and explain how they relate to each other.

“As you can see from Juma and Carole's comments, personal goal setting is a part of time management. You need to make goals for yourself every day to manage your time well."

9. Change the way participants interact or have the group evaluate ideas that have been presented.

"Let's break into smaller groups and list all the myths you have heard about pregnancy."

10. Summarize the major views of the group and confirm everything has been captured.

"I have noted four major reasons that have come from our discussion about why you think that young people do not abstain from sexual intercourse: (1) peer pressure, (2) low self esteem, (3) wanting to show their love for their partner and (4) wanting to feel like an adult. Did I leave anything out?" 


\section{Talking about Uncomfortable Topics}

Young people will often giggle with embarrassment or excitement when you talk about anything to do with sex or reproduction. Do not let this discourage you or make you uncomfortable. They need accurate information on these subjects in order to make healthy choices and feel more comfortable with the changes they are experiencing. Let the embarrassment or excitement pass, wait for them to settle down, and then focus on providing them with the information they need.

Young people can ask difficult questions and make shocking statements. Answer questions honestly, and if you do not have the answer, tell them you will find out and get back to them, or help them to find it. Try and sense if there seems to be more to their question. You could say, "You seem bothered about ... " or "I am wondering what made you ask that ...?"

\section{Tips for tackling difficult subjects}

Clarify your own values before you begin talking with young people. Think about how you feel about the issue before you discuss it with them.

Be prepared and plan ahead. If you are facilitating a health talk, decide what you want to achieve before the session. Find out as much information beforehand, so you feel confident facilitating the session.

You do not have to know everything. Sometimes you may not know the answer to a question. Be honest about it. There is no shame in saying "I don't know." You can turn it into an investigative project and ask them to help you find the answer, or tell them you will find the answer and bring it to the next meeting. Begin the next session by sharing your findings.

Do not dismiss or look down on what young people know. They have been exposed to a variety of information and experiences. Try to make them feel that their experiences have value and are important. Remember that you do not know everything about their lives.

Set your own limits. Participants will be excited because you are prepared to talk about topics that interest them. Few adults guide them or give them this knowledge and they may ask questions that make you feel embarrassed. It is important to be as open and honest as you can. But tell them when it is enough or when their behaviour is disrespectful. Explain if you feel uncomfortable answering a particular question. 


\section{Puberty}

Puberty is a time when the bodies of boys and girls physically change; bodies grow bigger and taller, genitals mature, and hair often starts growing in new places. During puberty, a girl becomes physically able to become pregnant and a boy becomes physically able to father a child. New chemicals produced by the body, called hormones, create changes in the body and turn young people into adults.

Puberty typically starts between ages 8 to 13 in girls, and ages 10 to 15 in boys, although some young people start puberty a bit earlier or later. People are different, so everyone starts and goes through puberty at their own pace. Puberty lasts for about 2-5 years. During puberty, young people are experiencing a major growth change. When the growth period is over, young people will be at their adult height.

\section{Body changes in boys}

Boy's shoulders will grow wider, and their bodies will become more muscular. Some body parts (especially hands and legs) may grow faster than others. Many boys have uncomfortable growing pains in their arms and legs as the bones grow faster than the muscles can stretch to keep up with them.

Some boys develop swelling underneath their nipples, which looks like the start of breasts. This is caused by the hormones that are active throughout the body and will usually go away with time.

During puberty, boys will start to have erections and wet dreams. An erection is when the penis gets stiff and becomes bigger than usual. They will notice other changes as well, such as the lengthening and widening of the penis and the enlargement of the testicles.

\section{Body changes in girls}

Girl's bodies usually become rounder and more womanly. They gain weight on their hips, and their breasts develop, starting with just a little swelling under the nipples. Sometimes one breast might develop faster than the other, but over time the slower one catches up. Girls will notice an increase in body fat and will occasionally feel sore under the nipples as the breasts start to enlarge; this is normal. Gaining some weight is part of developing into a woman, and it is unhealthy for girls to go on a diet to try to stop this normal weight gain.

About one to two years after girls' breasts start to develop, they usually experience their first menstrual period. This step is one more thing that lets them know puberty is progressing. It means that the puberty hormones have been doing their job.

Girls might see and feel a white or clear liquid coming from the vagina. This does not necessarily mean anything is wrong; it is usually just another sign of their changing body and hormones.

\section{More changes}

One of the first signs of puberty is hair growing where it did not grow before. Hair will grow in the armpits and in the pubic area (on and around the genitals). At first it is thin. Then it becomes longer, thicker, and heavier. Eventually, young men also start to grow hair on their faces and chests. Acne (pimples or spots) often starts around the beginning of puberty and can remain throughout adolescence. It usually gets better or disappears by the end of adolescence. Young adults should wash their faces each day with soap and water to keep their skin clean.

A new odour under arms and elsewhere on the body might develop. This is body odour, and everyone gets it. The puberty hormones affect glands in the skin and the glands make chemicals that have a strong odour. Bathing or washing every day helps reduce this odour, and so do perfumes or deodorants.

Boys will notice that their voices may "break" and eventually get deeper. Boys' voices will stop breaking as they get older. Girls' voices might get a little deeper, too.

During puberty, young people might become sensitive or easily upset. Feeling nervous or uncomfortable about how their bodies look and change is one of the things young people are most sensitive about. It is common for adolescents to lose their temper, get angry with friends or family more easily, and feel sad sometimes. 


\begin{tabular}{|c|c|c|}
\hline $\begin{array}{l}\quad \text { Physical Changes in Boys } \\
\text { Shoulders broaden } \\
\text { Facial hair grows } \\
\text { Voice deepens } \\
\text { Sperm production \& ejaculation begin } \\
\text { Wet dreams begin }\end{array}$ & $\begin{array}{l}\quad \text { Physical Changes in Girls } \\
\text { Hips widen } \\
\text { Breasts develop } \\
\text { Ovulation and menstruation begin }\end{array}$ & $\begin{array}{l}\quad \text { Physical Changes in Both } \\
\text { Growth } \\
\text { Weight gain } \\
\text { Pubic and underarm hair appear } \\
\text { Genitals enlarge } \\
\text { Acne appears }\end{array}$ \\
\hline
\end{tabular}

\section{Common changes in attitudes and behaviours}

Struggling with a sense of identity and questions about oneself.

Moodiness, anger and depression (being rude, self-centred).

Need for more independence and privacy.

Experimentation (taking risks, using drugs, having sex).

Identification with peers and forming strong relationships with friends. The opinions of peers and friends become more important than parents or other adults.

More concern or worry about appearance and body.

Worry about the future (school, family, job).

New "crushes" on movie stars, pop artists, teachers, friends or classmates.

Curiosity about sexual organs.

Feeling sexually attracted to people.

Better ability to reason (can learn quickly, can plan, more dependable).

\section{Male reproductive system}

Under the penis there is a small bag of skin containing the testicles. There are two of them and they produce sperm and testosterone. Testosterone is the male sex hormone and it makes pubic hair grow and boys' voices become deeper. Semen is the fluid that carries the sperm. Sperm makes babies when it joins up with women's eggs. Most of the time sperm is inside the body. There is only one exit for the sperm, which is through the hole at the end of the penis, called the urethra. When the penis is soft, that hole is used to urinate; when it is erect, it is used to release semen.

An erection occurs when the penis fills with blood and becomes hard and straight when a boy or man is sexually excited. Erections happen sometimes as boys fantasize and think about sexual things, or sometimes for no reason at all. Boys do not have any control over when this will happen. It is very common for boys to wake up with an erection in the morning. While asleep at night, a boy's penis will probably become erect and then go down about five to seven times. This is completely normal and healthy. Having erections is not a sign that a boy needs to have sex.

When the penis is erect, a boy will find that he cannot urinate easily because a muscle closes off the bladder. He will have to wait until the erection goes down before he can urinate. Ejaculation is when semen comes out of a boy's or man's erect penis due to sexual excitement. A man does not have to ejaculate every time he has an erection. If he waits, the erection will go down on its own without causing any harm.

When a boy begins puberty, the ejaculated semen tends to be slightly clear or slightly yellow. As the boy grows into an adult, he begins making a large amount of mature sperm, and his ejaculation will probably become more whitish. Boys are not born with sperm; they begin to produce them during puberty. A boy begins to produce sperm and continues to produce them through his entire life. If the sperm are ejaculated into the woman's vagina, she may become pregnant. The semen can also carry diseases that could infect another person.

A wet dream is when a boy's penis becomes erect, and he ejaculates while sleeping. Wet dreams are completely natural and normal. A boy cannot stop himself from having wet dreams. 


\section{Female reproductive system}

The female external genital organs are collectively called the vulva. The vulva includes the two folds of skin called the labia, the clitoris and the vagina. The labia have two sets of rounded folds of skin called the outer and inner lips. The labia cover and protect the vaginal opening. Near the top of the lips, inside the folds, is the clitoris. The clitoris is made up of the same type of tissue as the head of the male's penis and is very sensitive. The clitoris has no other function than to help a woman have sexual pleasure.

The vagina is the place where a man puts his penis during sexual intercourse. Also, menstrual blood and babies come out of the vagina. The vagina is an incredibly elastic muscle that can stretch wide enough to allow a baby to pass through.

Every female is born with thousands of eggs in her ovaries. The eggs are so small that they cannot be seen by the naked eye. Once a girl reaches puberty, a tiny egg matures in one of her ovaries and then travels down a fallopian tube on its way to the uterus. This release of the egg from the ovary is called ovulation. The uterus prepares for the egg's arrival by developing a thick and soft lining. If the girl has had sex in the last few days before or the day after she ovulates, there might be some sperm waiting to unite with the egg in the fallopian tube. If the arriving egg is united with the sperm (called fertilization), the fertilized egg travels to the uterus, attaches to the lining of the uterus (called implantation), and a pregnancy begins. If the egg is not fertilized, there is no pregnancy and the uterus does not need the thick lining it has made to protect the egg. It discards the lining, along with some blood, body fluids, and the unfertilized egg and all of this comes out of the vagina. This flow of blood is called the "period" or menstruation. The blood and tissue usually leave the body slowly over three to seven days.

\section{Menstruation and ovulation}

Menstruation happens for most women about once a month, and that is why it is commonly called the "monthly period." It usually lasts between three and seven days. It is a sign that a girl or woman can become pregnant if she has sexual intercourse. Women stop menstruating when they are pregnant and may or may not menstruate breastfeeding.

Just as some girls begin puberty earlier or later than others, the same applies to periods. Some girls may begin to menstruate as early as age nine or ten, but others may not get their first period until a few years later. A woman knows that she has started her period when a little blood comes out of her vagina. The blood does not pour like water from a tap. It comes out slowly, like a dribble. Usually by the time she has noticed a feeling of unusual wetness, her panties have absorbed any blood that has come out. This is why it is important to anticipate approximately when each month she will start bleeding, so she can wear a sanitary pad or other protection to prevent the blood from staining her clothing.

The amount of blood that comes out of the vagina can vary widely from person to person. Usually, an entire period consists of a few to several spoonfuls of blood; the amount of blood depends on the individual. The blood often starts off as a rusty or deep brown colour and then gets redder. It lightens to a rust colour again until it stops. The amount of blood can also vary from day to day.

The menstrual cycle is the period of time beginning on the first day of a woman's period until the day before she begins her next period. Since this happens regularly, it is called a "cycle." The length of the menstrual cycle (the time between one period and the next) varies for each woman. For some, the cycle is as short as 21 (or even fewer) days. For others, it is as long as 35 days or more. Irregular periods are common in girls who are just beginning to menstruate. It may take the body a while to adjust to all the changes taking place. For example, a girl may have the same length cycle for two months, then miss a month, or have two periods with fewer days in between them. Her menstrual cycle will probably become more regular, though she may continue to have irregular periods into adulthood. Sometimes she might have some spotting of blood for a day or two in the middle of her cycle. This is usually nothing to worry about. It is important to note that a regular menstrual cycle may be disrupted by stress or infection.

Ovulation is the periodic release of a mature egg from the ovary. The time from ovulation to the next period is a very consistent length of 12 to 16 days and is controlled by hormones. The two weeks or so before ovulation and the two weeks after make a menstrual cycle about four weeks or a month in length. 


\section{Sexuality}

Sex and sexuality are often thought of as sexual intercourse and other activities. However, sex is whether a person is male or female and is determined by reproductive organs and how people express their gender. Sex is a part of sexuality.

Sexuality is an important part of who a person is and what she or he will become. It is much more than sexual feelings and sexual intercourse. Sexuality includes thinking of oneself as a sexual being, feeling attractive, and behaving, dressing or communicating in a sexy way. It includes feeling, thinking or behaving as a male or female, being attractive, being in love and being in relationships with sexual intimacy and sexual activities.

Human sexual choices are influenced by society and culture. Some may choose to abstain from sex before marriage because of their family values or religious beliefs. Our culture, traditional beliefs and gender roles play an important part in defining what we consider normal sexual feelings and behaviour for men and women. For example, some cultural traditions recognize that women have sexual desires and urges whereas other cultures do not. It some cultures it is very important for girls to be virgins when they get married, whereas men are expected to be sexually active by the time they are married.

\section{Aspects of sexuality}

There are many aspects that make up sexuality. Each of these are connected and make a person who he or she is. The following are aspects of sexuality:

Body image: How we look and feel about ourselves, and how we appear to others.

Gender roles: The way we express being male or female. The expectations people have for us based on our sex.

Relationships: The ways we interact with others and express our feelings for them.

Intimacy: Close sharing of thoughts or feelings in a relationship, may or may not involve physical closeness.

Love: Feelings of affection and how we express those feelings for others.

Sexual arousal: The different things that excite us sexually.

Social roles: How we contribute to and fit into society.

Genitals: The parts of our bodies that define our sex. They are part of reproduction and sexual pleasure.

\section{Healthy sexuality}

An important part of healthy sexuality is being able to tell the difference between sexual behaviours that are healthy and those that are harmful. Before adolescents act on their sexual feelings, it can be helpful for them to think about the consequences of their actions. They should be encouraged to ask themselves:

Will I or anyone else be put at risk for unwanted pregnancy, HIV or other STIs?

Will acting on my sexual feelings cause any other problems, such as misunderstandings or miscommunication in our relationship?

Will it make me or my partner feel uncomfortable? Will anyone's feelings get hurt?

Being sexually healthy means taking the time to think about these things before acting on sexual feelings. 


\section{Unintended Pregnancy}

Ten thousand girls drop out of school every year in Kenya because of unintended pregnancy. Several factors contribute to this problem: parents do not generally talk with their children about sex; adolescents lack information about their bodies; and they may not understand how to control the new sexual urges they experience. Unintended pregnancy can be addressed by giving young people information and teaching them skills that will help them make appropriate decisions, be assertive and resist early sexual activity.

There are several medical and social reasons to delay childbearing.

\section{Medical reasons to delay childbearing}

A young woman under age 16 has not reached physical maturity. She may suffer prolonged labour or other problems with delivery which can lead to health problems or even death of the mother or the infant.

Young women, especially those under age 15, are more likely than women age 20 and older to experience premature labour, spontaneous abortion (miscarriage) and stillbirths.

Infant death rates are typically higher for adolescent mothers than for women over 20.

\section{Social reasons to delay childbearing}

Young women can pursue formal education, work outside the home and achieve their future goals.

Men can pursue education and jobs without the pressure of providing for a family.

Delayed pregnancy can mean smaller families and can offer economic benefits.

Pregnant girls often drop out of school and few girls return to school after giving birth.

The responsibility for caring for a child, as well as limited education because of school drop out, reduce a young woman's access to jobs and income-earning opportunities.

Some young women find themselves rejected by the father of the child, or even by their own families.

\section{Unsafe Abortion}

Abortion, as it is commonly used, is the deliberate early termination of a pregnancy. Abortion is currently legal in many countries around the world and is practiced safely by trained health care providers. In Kenya, abortion is legally very restrictive (only to save the life of the mother) and as a result, is often practiced under unsafe and unhygienic conditions.

Some unsafe methods of abortion that have been tried by girls include: chemical abortions, overdose of quinine (malaria medication), herbal medications, mechanical methods including piercing the uterus using sharp objects, and taking concentrated solutions such as quencher, millet chuff and tea leaves.

Many women have died from unsafe abortions or have developed health problems. Some immediate health complications include severe bleeding or infection, which can lead to death. Some women suffer from longterm problems including not being able to get pregnant again or living in constant pain.

A girl or woman who has recently had an abortion needs to consider contraception options. She should make a plan for getting contraception immediately after the procedure. If the abortion was not carried out by a skilled provider, she may not have access to contraceptives. An adult who is aware of this situation can help the girl seek medical care and contraceptive counselling.

Abortion can be spontaneous or induced. A pregnancy that ends spontaneously is called a miscarriage. Most abortions occur spontaneously in the first 12 weeks of pregnancy. One that happens by choice, before the foetus is big enough to live outside the uterus (before 28 weeks), is called an induced abortion. An induced abortion is a pregnancy that is ended for medical reasons (to save the mother's life) or is done voluntarily for other reasons. The safest way to induce an abortion is to have it performed by a trained health provider. 


\section{Sexually Transmitted Infections}

\section{Germs, viruses and bacteria}

Germs are tiny living organisms, or things, that cause disease when they enter the body. They are so tiny you cannot see them with your naked eye. Bacteria and viruses are both types of germs.

Viruses are the smallest germs known to man. In order to multiply, viruses must find a home inside a living organism, like a human cell. Some of the diseases caused by viruses include measles, polio, hepatitis, chicken pox, the common cold (homa) and HIV.

Many bacteria are useful, such as those that ferment beer or turn milk into yoghurt. However, many also cause disease in humans. Some diseases caused by bacteria include gonorrhoea, syphilis, meningitis, diarrhoea, pneumonia, and leprosy.

\section{Sexually transmitted infections}

Sexually transmitted infections (STIs) occur when bacteria, viruses or other disease-causing organisms pass from one person to another through sexual activity. STIs can have devastating health consequences, including infertility, chronic abdominal pain, cervical cancer and in some cases, death. In addition some STIs can be transmitted to infants during pregnancy or birth. HIV is the STI that leads to AIDS, which is fatal. In addition to HIV, there are more than $\mathbf{2 0}$ other diseases that can be sexually transmitted, including chancroid, Chlamydia, gonorrhoea, genital herpes, the human papilloma virus, syphilis and trichomoniasis, among others.

It is possible to become infected with an STI even after only one act of sexual intercourse with an infected person. Some STIs can no longer be treated successfully with the medicines that were used in the past, because the germs that cause the disease are now resistant to the medicines. For these reasons, STIs are becoming more common in many areas.

\section{Girls are more at risk}

Women are at higher risk for becoming infected with STIs than men for several reasons. Differences in their bodies make detection more difficult in women, infection has more serious consequences for women than for men, the risk of transmission is greater from man to woman, and many women have little power to protect themselves in sexual situations. Additionally, because a man's sexual fluids stay inside a woman's body after sex, she is more likely to get an infection. Younger girls are even more at risk for getting an STI because they are more likely to suffer from tears in the vagina during sex.

\section{STI prevention}

The only completely effective preventive measure is to abstain from vaginal, anal or oral sexual intercourse. Maintaining a mutually faithful relationship or using condoms to protect their partner and themselves can reduce the risk of STI infection. Maintaining a mutually faithful relationship requires the commitment of both partners. Condoms can help prevent many, but not all, STIs.

\begin{tabular}{|l|}
\multicolumn{1}{|c|}{ Risk factors for STIs } \\
Having a sexual partner who has an STI \\
Having more than one sexual partner \\
Having a sexual partner who has other \\
sexual partners
\end{tabular}




\section{Signs and symptoms of STIs}

Most men can tell when they have an STI because there are usually clear signs. Women, however, often have an STI without knowing it, because there are frequently no signs that they have the disease. Sometimes only an experienced and trained health care provider can find signs of an STI in a woman. This is especially true during pregnancy, when many STI symptoms (for example, an increase in the amount of fluid produced in the vagina) are mistaken for side effects of pregnancy itself. Sometimes it is necessary to examine samples of a woman's blood or vaginal discharge to find out if she has an STI, and which type of STI she has. For this reason, it is important to recognize the signs of an STI and to visit a doctor as soon as possible if you see any of the signs or suspect that you have been exposed to an STI.

Many STIs can be cured or treated (refer to Appendix $x$ for more detailed information on STIs). A health provider will give medicine to a person who has been diagnosed with an STI. It is essential that a person with an STI finish all the medicines that the health worker gives and not engage in unprotected sex until the health worker says they are cured. If a person finds out that they have an STI, they should also make sure that their partner (or partners) goes for treatment as well.

Any of the following can indicate to a person who has had sexual intercourse that she or he may have an STI and should consult a doctor or clinic:

Redness or soreness of the genitals

Pain at urination or cloudy or strong-smelling urine

A sore or blisters on or around the genitals, near the anus, or inside the mouth

Excessive itching or a rash

Abdominal cramping/pain

A slight fever and an overall sick feeling

A sexual partner with symptoms

Note: Both men and women can have an STI without physical symptoms. However, women are more likely to be symptom free. The complications from STIs are more severe in women than in men.

\section{Someone with an STI should:}

Seek medical treatment immediately and complete their treatment and not share their medicine with a partner or anyone else.

Inform their sexual partner(s).

Strongly encourage their partner(s) to get treatment.

Abstain from sexual contact while infectious.

Protect themselves and their partners every time they have sex in the future. 


\section{HIV and AIDS}

HIV stands for Human Immunodeficiency Virus. HIV is a virus that is passed between people through contact with infected blood, semen, vaginal fluids and breastmilk. HIV weakens the immune system, making it easier for people to become sick. When a person with HIV becomes sick with many illnesses that do not respond to treatment, he or she is said to have AIDS. AIDS stands for Acquired Immunodeficiency Syndrome. Acquired refers to the fact that you get the disease from somewhere else; it does not develop on its own. Immunodeficiency means the immune system is weak and unable to fight off infections and illnesses. Syndrome means a specific collection of symptoms and diseases, such as weight loss combined with skin cancer and pneumonia. AIDS is a term used to indicate the most serious stage of a person's infection with HIV. It means that they have a particular collection of symptoms and diseases defined medically as AIDS.

After years of living normally with HIV, a person will start developing AIDS, as the immune system begins to weaken. At this state, the person will be vulnerable to various opportunistic infections, which can attack any part of the body. Opportunistic infections are infections that take attack the body when the immune system is weak. These infections could range from simple medical conditions like fungal infections and colds to more serious diseases like tuberculosis or cancer. Though the person is HIV positive, these conditions can be treated and often cured. There is no cure for HIV or AIDS.

\section{How is HIV transmitted?}

HIV is passed between people in three ways:

Sex. Penetrative sex with an HIV-infected person where the penis enters the vagina, anus, or mouth of another person.

Blood to blood. From an HIV infected person's blood to another person's blood through an opening in the body such as a cut, from a transfusion or by sharing something that cuts or pierces the skin (knife, razor, needle). This includes sharing circumcision knives, needles, tattooing or ear piercing, with someone who has HIV.

Mother to child. HIV can be passed from a mother who is HIV infected to her baby during pregnancy, at the time of birth, or through breastfeeding.

The majority of people are infected with HIV by having sex with someone who is HIV infected. It is important to note that a person suffering from other STIs is eight to ten times more likely to contract HIV.

You cannot get HIV infection from:

Touching, hugging, talking to, or sharing a home with a person who is HIV infected or has AIDS.

Sharing plates, utensils, glasses or towels used by someone with HIV or AIDS.

Using swimming pools, toilet seats, doorknobs, telephones or other items used by people with HIV or AIDS.

Having someone with HIV or AIDS spit, sweat or cry on you.

Being bitten by mosquitoes.

Donating blood.

Being sneezed at or coughed on by a person with HIV or AIDS. 


\section{Protecting against HIV}

The only certain way to protect against HIV transmission is to abstain from sexual intercourse.

\section{What is safer sex?}

People who have decided to be sexually active can make choices to practice safer sex. Safer sex describes a range of ways that sexually active people can protect themselves from sexually transmitted infections, including HIV. Practicing safer sex also provides protection against pregnancy. There are lots of ways for loving and sexual feelings to be shared that are not risky. Some of them include:

Hugging
Holding hands
Kissing

Massaging

Rubbing against each other with clothes on

Sharing fantasies

Touching your partner's genitals, as long as males do not ejaculate near any opening or broken skin

Maintaining a mutually faithful relationship or using condoms to protect their partner and themselves can reduce the risk of STI infection. Maintaining a mutually faithful relationship requires the commitment of both partners. For young people it does not mean having a faithful relationship for a short time then starting a new relationship with someone else. This may be most appropriate for married adolescents.

Using a latex condom correctly for every act of sexual intercourse is called protected sex because when used correctly for each sexual act, condoms can significantly reduce the risk of HIV infection. Although condoms significantly reduce the risk of transmission, they are not 100 percent effective in preventing HIV infection. Unprotected sexual intercourse (without a condom) exposes people to the bodily fluids in which HIV lives.

\section{What does HIV-positive mean?}

When the body's defence system (immune system) comes into contact with a disease, it produces germ fighters, called antibodies, which fight off and destroy various viruses and germs that invade the body. An antibody is found in the blood and it tells us that the person has been infected with a particular germ or virus.

HIV tests look for HIV antibodies. If the body is making antibodies to fight HIV, then someone is considered HIV positive. However, there is a "window period" between when a person is infected with HIV and when a blood test shows that a person is HIV-positive, because it takes the body a little while to start producing antibodies to fight the virus. It is possible for someone to test HIV-negative during this window period but be infected with HIV, this is called a false negative. During this time, people who are HIV infected are able to transmit the virus to others. The window period is generally three months but in very rare cases could be six months.

People who have a negative test result and have had unprotected sex during the past three months are advised to go for another test in three months. While waiting through the window period, they must avoid being exposed to HIV.

\section{When are people with HIV infectious to others?}

People with HIV can infect others as soon as they are infected with the virus. People with HIV may not know they are infected and may look, act and feel healthy for a long time, possibly longer than 10 years. It is impossible to tell from looking at someone if he or she is infected. 


\section{From HIV to AIDS}

As with other infections, when HIV enters the body, the immune system produces a response to try to fight off the infection, by producing antibodies. However, these are insufficient to battle against the growth and multiplication of the virus, which slowly destroys key cells in the immune system. HIV slowly weakens the immune system and eventually the body cannot fight off even mild infections. At this point, people become very sick from a range of different illnesses, including the common cold, fungal infections, cancer, or tuberculosis.

Most people who have HIV do not become sick right away. In some cases, it can take as many as 10 years or more for a person to develop AIDS. People can stay healthy longer by eating well and getting prompt treatment of illnesses and infections.

The most obvious signs that someone has AIDS are diseases such as tuberculosis or pneumonia. However, the following can also be signs that someone has AIDS:

Sudden, unexplained weight loss

Fever for more than one month

Diarrhoea for more than one month

Genital or anal ulcers for more than one month

Cough for more than one month

Enlarged lymph nodes

Skin infections that are severe or recurring

Although the above can all be symptoms of AIDS, the only way to tell if a person is infected with HIV is by testing, because the above can be symptoms of other illnesses or diseases.

\section{Frequently asked questions about HIV and AIDS}

\section{Can HIV be transmitted through kissing?}

There are no reported cases of people becoming infected with HIV just from deep kissing. HIV is rarely found in saliva. It might be risky, however, to kiss someone if there is a chance for blood contact if the person with HIV has an open cut or sore in the mouth or on the gums. It would be even more risky if both people had bleeding cuts or sores in their mouths. People should use common sense and should wait until any sores or cuts have healed before kissing.

\section{Can a person get HIV infection from a mosquito?}

When mosquitoes bite someone they do not inject the blood of the previously bitten person into the next person. They use their saliva as a lubricant. Diseases like malaria are spread through mosquito saliva. HIV gets digested in the mosquito's stomach before it can find its way to the saliva.

\section{If a person tests negative for HIV does it mean he or she cannot catch it?}

A negative HIV test result means the person is not infected at the time or possibly that they have the infection and it is still in the window period. They can still become infected if they have unprotected sex with someone who is infected.

\section{Is there a cure for HIV?}

There is still no cure for HIV. People should be very cautious about claims that a "cure" for AIDS has been discovered unless these claims have been medically proven. 


\section{Voluntary Counselling and Testing}

It is not possible to know if a person has HIV by looking at him or her. The only way for people to know if they have HIV is to have a test for HIV. In Kenya, HIV testing is accompanied by counselling, which usually refers to in-depth discussions with a trained person who can help individuals cope with their HIV status. Individuals learn how to take care of themselves if they are positive or prevent the disease if they are negative. This process is called voluntary counselling and testing, or VCT.

The test is reliable, accurate, safe and painless. The health worker takes a small amount of blood from an individual's finger. The person tested cannot get weak from blood loss because so little blood is taken. Depending on the type of test used, the result may be available in just 30 minutes or after a week. In order for an individual to know whether they are truly free from HIV, they will also be asked to come back in another 3 to 6 months for another test when the window period is over.

The window period is the time between when HIV enters the body and the moment when the test can detect HIV antibodies. Usually the test can detect antibodies within three months of infection and in rare occasions, up to six months. This means that for months after infection, the test may not be able to tell whether or not someone is infected. These months are known as the window period. During this window period, it is possible to infect others with HIV.

There are many reasons to get tested for HIV. If a person has had unprotected sex and is worrying constantly about HIV infection and is nervous about every spot or cough, the only way to put his or her mind at ease might be to have an HIV test. If a person has had sex with someone who has fallen sick and has AIDS, then that person will also worry. Perhaps the only way for that person to put his or her mind at ease is to go for VCT. People should never assume that they are infected or that they are not infected. The should always go for a test.

Physicians currently recommend HIV testing to people who engage in high risk behaviour including:

Frequent sexual activity with multiple partners

Encounters with sex workers

Previous treatment for STIs

Blood transfusions

Anal sexual activity (male or female)

Injection drug use

Sexual activity with partners having any of the above

Children born to women with any of the above 


\section{Care and Support for People with HIV and AIDS}

Many people who learn that they are HIV positive are unaware that it can be many years before their infection turns to AIDS. Thinking that they will die soon, they may give up on life. In Kenya, thousands of young men and women who test positive stop working, leave home, abandon their families, commit suicide, or begin living recklessly, because they feel they have nothing to live for. With support from family and friends, and continued counselling, an HIV-positive person can overcome his or her turbulent feelings, and return to life with new determination and optimism.

It is important for people with HIV to understand that it is normal to have a variety of different feelings. With counselling and support, a person can begin to accept his or her condition and make the best of the remaining time. Acceptance means adding more life to your days rather than trying to add more days to your life.

\section{Treatment}

A cure means that the germ that causes a disease has been completely killed or eliminated from the body and will not return unless a person is re-infected. There is no cure for AIDS. However, there are ways to treat the symptoms. Treatment means the use of a drug, injection, or intervention that can cause symptoms to become less painful or pronounced or cause them to disappear altogether. A treatment may not always lead to a cure (in the case of HIV and AIDS, it will not lead to a cure).

When looking at health, physical health is only one part of total wellbeing. Treatment in its broadest sense can mean any intervention that helps improve any aspect of our wellbeing. There are many strategies people can use to prolong their life and improve its quality even if they are infected with HIV. This concept is very important, especially for those struggling to cope with HIV without access to anti-retroviral therapy.

The table below lists some ways to improve the overall wellbeing of people living with HIV and AIDS:

\begin{tabular}{|c|c|c|c|}
\hline $\begin{array}{l}\quad \text { Physical } \\
\text { Proper nutrition } \\
\text { Rest } \\
\text { Exercise } \\
\text { Preventing and treating } \\
\text { infections and illnesses } \\
\text { Avoiding drugs and alcohol } \\
\text { Proper hygiene } \\
\text { ART }\end{array}$ & $\begin{array}{l}\quad \text { Psychological } \\
\text { Having a positive attitude } \\
\text { Building self- esteem } \\
\text { Counselling } \\
\text { Reducing stress }\end{array}$ & $\begin{array}{l}\qquad \text { Social } \\
\text { Supportive family and } \\
\text { friends } \\
\text { A social system that protects } \\
\text { one from discrimination } \\
\text { Continuing productive } \\
\text { work } \\
\text { Being involved in advocacy }\end{array}$ & $\begin{array}{l}\quad \text { Spiritual } \\
\text { Having faith or a belief } \\
\text { system } \\
\text { Prayer } \\
\text { Meditation }\end{array}$ \\
\hline
\end{tabular}

People with HIV and AIDS can live long, healthy lives if they take care of themselves by eating well, practicing good hygiene, staying active, and going to the doctor as soon as they have symptoms of infection or fall ill. The goal of living positively is to be free of illness, to be productive, and to stay emotionally and physically healthy.

\section{Staying healthy}

It is important for people with HIV and AIDS to eat a nutritious diet to fight infection and disease and to stay energetic, strong, and productive. Nutrition and HIV are strongly related to each other. People who are malnourished are more likely to progress faster to AIDS, because their bodies are weak and cannot fight infection. People with HIV and AIDS are at risk of malnutrition because they eat less, have infections that require more energy, and lose the ability to use food effectively in their bodies. People with HIV and AIDS need to eat more than people who are not infected. Eating small meals often and eating a variety of foods can help people with HIV and AIDS to get all the energy and nutrients they need. 
People with HIV should:

Eat at least three meals a day, and have snacks between meals.

Eat even when they are sick or have no appetite.

Eat plenty of fruits and vegetables of different colours.

Drink plenty of fluids especially cool boiled water and unsweetened fresh fruit juices.

Eat fats, oils and sugars in small quantities and limit processed foods, salt, coffee, tea, and sodas.

Avoid alcohol, smoking, raw eggs, raw fish, and partially cooked meat.

Practicing good hygiene is important for everyone to avoid infection. It is especially important for people with HIV and AIDS because they have weak immune systems and are more vulnerable to infection. Handle and store food and water properly and wash hands with soap and clean water to avoid contamination and further infection.

People with HIV and AIDS should go for regular medical check ups and seek treatment immediately for all infections and illnesses. They should be encouraged to continue with daily activities, like doing housework, and exercise regularly.

\section{Anti-retroviral therapy}

ART (anti-retroviral therapy) is the use of a combination of medicines that slow HIV from spreading in the body. ART helps the immune system get stronger so it can fight infection and illness. ART is not a cure for HIV; it reduces the numbers of HIV in the blood, but cannot eliminate it. ART does not prevent against re-infection from HIV.

Although anti-retroviral therapy can prevent some of the serious illnesses that often come with AIDS, there are some negative aspects that HIV-positive individuals must be prepared for: ART is expensive, has side effects and is a lifetime commitment. If someone misses his or her tablets, it can cause the development of new strains of HIV that are immune to these drugs. 


\section{Abstinence}

Saying no to sex can be difficult for many young people. There may be pressure from peers who claim "everyone" is having sex, pressure from partners who argue that sex is the best way to prove love and affection, or pressure from older friends and relatives who say having sex is a way to be an adult.

Adolescents may not feel they have many choices, but you can explain to them that they can say no to sex if they are not ready. You can help them develop refusal skills by counselling them about abstinence or delaying sexual activity. One way to do this is to help them imagine situations in which they might find themselves and help them practice saying no.

Abstinence is a voluntary, conscious, and deliberate decision not to do something. In the context of sexual intercourse, HIV, and unwanted pregnancy, abstinence means not having sexual intercourse until marriage. Abstinence is the best and only certain way to prevent HIV transmission and unwanted pregnancy. Even people who have already had sexual intercourse can decide to abstain from now on. This is called secondary abstinence.

Telling young people to abstain or say no to sex is not enough; young people should be encouraged to discuss ways to abstain. Young people need support and skills to successfully abstain. Gaining self-esteem and sustaining self-control in all matters including sex are best developed early in life.

\section{Assertiveness}

Assertiveness skills can help young people say no to sex. Being assertive means standing up for yourself. To be assertive is to be straightforward and honest with yourself and with other people about what you need and want. Being assertive can help you protect yourself from dangerous situations and can help you deal with peer pressure to do things that you are uncomfortable doing.

People who are not assertive often lack the confidence and self- esteem to stand up for their own needs and to protect their feelings or body from being hurt. Assertiveness is very different from being aggressive. People who are aggressive are rude and unkind.

\section{Assertiveness tips for young people}

Decide what you feel or want and say it. Don't be afraid to be honest about your feelings. Being confident about your own feelings will encourage others to respect them as well. Someone who truly loves you will not want to do things that make you feel unhappy.

Do not make excuses. Your feelings are the best reasons. For example, if you do not feel ready for sex, but your girlfriend or boyfriend is pressuring you, avoid using other people as excuses. Say what you really feel.

Do not seek approval from others. If you do not want to do something, say so clearly and do not ask if it is okay. Show other people that you know your own mind and are not looking for their approval.

Do not get confused by the other person's argument. Keep repeating what you want or do not want. Focus on what you want and do not give in.

Remember you have a right to change your mind. Perhaps you and your boyfriend talked about sex a few days ago and you told him that you would have sex with him. But you have had another couple of days to think it over, and now you feel sure that the time is not right - that you are not ready and that the relationship is not ready. If he or she truly loves you, he or she will respect your right to change your mind, and will wait until you feel ready. 


\section{Condoms}

Abstinence is the best and only certain way to prevent STI and HIV infection and unwanted pregnancy. However, if young people have decided to have sexual intercourse or are sexually active, they should have information about how to use condoms correctly to reduce, but not eliminate the risk of HIV transmission. Using condoms correctly for every act of sexual intercourse can significantly reduce the risk of HIV transmission, STIs, and unwanted pregnancy.

There are currently two types of condoms available for use: a male condom and a female condom. A male condom is a soft, tube-like sheath made out of latex (a type of rubber) that is put on a man's erect penis before sexual intercourse. When the man ejaculates, the sperm is deposited in the condom. Because the sperm is collected in the condom, there is no contact between the man's and the woman's body fluids and this reduces the risk of STIs, including HIV, and unwanted pregnancy. It should only be used once and then thrown away.

A female condom is a plastic pouch that covers the vagina, and part of the external genitals. A woman uses the female condom during intercourse to prevent HIV, STIs, and unwanted pregnancy. It is a thin polyurethane (a kind of plastic) sheath with two flexible rings, one attached to each end. One ring, at the closed end of the sheath, is placed inside the woman's vagina and serves as an anchor. The other ring at the open end of the sheath stays outside the vagina and partially covers the lips of the vagina. It is also used once and then thrown away. The condom catches the man's sperm so that it does not enter the vagina.

Many men and women are afraid to use condoms because they do not know how to use them or because they are uncomfortable or worried about talking with their partner about using them. Condoms offer protection to both partners. Using a condom is a sign of trust, respect, and caring for your partner.

To be effective, condoms must be stored properly and used correctly for every act of intercourse. Most condoms are effective in preventing STIs that are transmitted through body fluids, including HIV, gonorrhoea, and Chlamydia. They are less effective against STIs that are transmitted through skin-to-skin contact (like genital herpes or warts) because the condom may not cover the entire affected areas.

\section{Condom facts}

No penis is too big or too small for a male condom. Male condoms can be stretched to fit over a forearm.

Asking a partner to use a condom does not mean you do not trust your partner. You are making a responsible statement about both your futures by using condoms.

HIV cannot pass through latex or rubber condoms; however, the virus can pass through sheepskin or animal skin condoms.

Most condoms are lubricated. However, if extra lubrication is desired, use a water-based lubricant such as KY jelly. Never use any lubricant that is oil or petroleum based like Vaseline, valon or other petroleum jelly in the market. This will weaken the rubber, and the condom can break.

Condoms are tested in the factory. They usually will not break if they are stored properly prior to use. Keep them away from heat or sunshine. Never leave condoms on a windowsill or in a wallet in your back pocket that you sit on continuously. All these storage methods will cause the condom to tear or lose its lubrication.

There is a correct way to use condoms. Not using a condom correctly may lead to pregnancy or infection with an STI including HIV. 


\section{Preventing Pregnancy}

Contraception means preventing pregnancy. A contraceptive is a drug, device, or other method used to prevent pregnancy or reduce the chances of getting pregnant without avoiding sexual intercourse. There are many different contraceptive methods. Most are reversible; that is, a woman is able to become pregnant after she has stopped using the method. Some methods, such as surgical sterilization, are permanent, meaning a woman cannot become pregnant or a man cannot impregnate a woman ever again. All methods are designed to work in one of two ways: either they prevent the man's sperm and the woman's egg from coming together, or they prevent the fertilized egg from implanting in the womb. Contraception allows women and men to determine the number and spacing of their children freely and responsibly.

\section{Contraceptive choices}

A variety of methods exist, including condoms, implants, injectables, IUDs, natural family planning, oral contraceptives ("the pill"), spermicides, vaginal barrier methods, voluntary surgical sterilization, and withdrawal. Each of these has their advantages and disadvantages. Some provide temporary contraceptive protection while others are permanent. Some, such as the male and female condoms, protect the user against sexually transmitted infections while others do not. Some are for women and some for men. Some must be used at the time of sexual intercourse, while others can be used independently of intercourse.

Some contraceptive methods are highly effective at preventing pregnancy, while others are only moderately effective. Effectiveness is closely linked to correct and consistent use for some methods.

\section{Talking with young people about contraception}

The subject of contraception is a sensitive one for many. Giving contraceptive information to adolescents can be controversial. Some adults believe young people should not have sexual intercourse and they fear that giving them information about contraception encourages young people to experiment sexually. There is no evidence to suggest that teaching this material causes young people to have sexual intercourse. In fact, studies from many countries show that good family life education actually postpones or delays sexually activity.

Do not assume that anyone in the group is having sex or that no one in the group is having sex. Make it clear that since most people have sexual intercourse at some point, it is important to know about contraception.

Always present abstinence as the most effective and most appropriate method of contraception for young people. Stress that when young people do choose to have sexual intercourse, they have a responsibility to themselves, their partner(s), and future children to keep themselves safe from unintended pregnancy and infection.

Always keep the diversity of religious and cultural values in mind. As you talk about making decisions about contraceptives, remind students that couples must always consider their personal, family and religious values.

Use the third person. For example, say things like "If a couple goes to a clinic..." or "When two people decide to have sex..." Do not say, "If you decide...." or "When you go to a clinic..."

Keep your personal values regarding contraception out of the discussion. Provide factual information about all the different methods.

Do not share your own personal experience with contraceptive use. You can say things like "Many women (couples, men) who use this method find..." or "One of the problems I've heard about it is..." Sharing personal sexual experience with the group is inappropriate. 


\section{Drug Use}

Drug use is the use of any chemical substance that causes physical, mental, emotional, or social harm to an individual or to the people close to him or her. Drug addiction is the use of drugs despite the social, emotional, or physical harm they may cause the individual or those around them. Some drugs are more addictive than others, and some people are more likely to become addicted than others. Some legal substances, such as caffeine, cigarettes, alcohol and medicines are addictive and can be abused. A recent study by NACADA indicated that one in every three secondary school students takes alcohol in Kenya.

Some predictors of drug and alcohol use, experimentation, and abuse include:

Family factors: Adolescents who observe their parents using or abusing drugs, alcohol, and other addictive substances are more likely to use or abuse them. Other family risk factors include parental absence, inconsistent discipline, poor (or lack of) communication, conflict between parents and adolescents, death of parents due to HIV and AIDS, and family breakup.

Early antisocial behaviour: Adolescents who show early antisocial behaviour may be more likely to use or abuse drugs. Drug use may occur as part of other self-destructive behaviour.

School factors: A range of school problems and pressures, such as poor performance, frequent absences, early drop out, placement in special classes, or low interest in education, may result in use or abuse of drugs by adolescents.

Peer factors: Spending time with peers who use drugs is perhaps the strongest predictor of adolescent substance use. Peers who are already involved with drugs may encourage others to use drugs through peer pressure, by providing drugs, and by showing others how to use them.

Attitudes, beliefs and personality traits: Some traits include poor relationship with parents, low interest in education, and feelings of being disconnected from normal societal behaviours and values.

Response to stress: Substance and drug use in adolescents may be the result of a feeling of a loss of control, a sense of meaninglessness, or a lack of direction in life. Teenagers may use drugs to feel better about life events that they see as being out of their control.

\section{Signs and symptoms of substance abuse}

The following behaviour changes, when extreme or lasting for more than a few days, may be signs of drug use:

Sudden changes in personality without another known cause

Loss of interest in favourite hobbies, sports, or other activities

Sudden decline in performance or attendance at school or work

Changes in friends and reluctance to talk about new friends

Deterioration of personal grooming habits

Difficulty in paying attention or forgetfulness

Sudden aggressive behaviour, irritability, nervousness, or giddiness

Increased secretiveness, heightened sensitivity to inquiry 


\section{Sexual Violence}

For many young people, sex is not a choice. Rape is defined by the Kenyan law as having sex with a woman or girl without her consent or with consent obtained under threat, force, intimidation, fear of bodily harm or misrepresentation. Defilement happens when sex occurs with a person that the law defines as too young to legally consent (in Kenya, girls below 16 and boys below 14) even with his or her permission. Date or acquaintance rape refers to rape that occurs between individuals who are dating or who know each other. Sexual violence includes the use of sexual contact by one person to another against his or her will. It can result in serious physical injuries, profound psychological trauma, unwanted pregnancy and infection with STI including HIV.

Some adolescents are forced to have sexual relations, feel pressured to have sex in exchange for good grades or pocket money, are assaulted if they refuse to have sex or sell sex in order to survive. Every adolescent should know that his or her sexual organs are private and personal property. Nobody should touch them without permission. Some victims of sexual abuse are assaulted by family members or acquaintances. Often young children are the victims of incest (a young person may be forced to touch, kiss or feel the sex organs, or have actual sexual intercourse with a relative). Because of the older person's position in the family, he or she may be able to pressure the child into doing sexual things without actually having to use force. These crimes, including rape, are the fault of the perpetrator or older person and not the fault of the victim or child. For girls and women, the short-and long-term consequences of sexual violence can be physically and emotionally damaging. Because of the sexual nature of rape crimes, victims often suffer from serious mental issues. If someone is raped and reports it to you, you should encourage them to go to a hospital or health centre. At the hospital they will have a medical evaluation and attention to any injuries, counselling support for the survivor and her family, and treatment to prevent infection with HIV, pregnancy and other sexually transmitted infections. Referrals to other services may be required.

Note: If a young person has been raped they can use Emergency Contraceptives (EC) to prevent pregnancy within 120 hours (5 days). They can use Post Exposure Prophylaxis (PEP) to prevent HIV infection. PEP is the administration of one or a combination of anti-retroviral drugs for 28 days after exposure HIV.

\begin{tabular}{|c|c|}
\hline What to Do if Assaulted or Harmed & What to Do if Raped \\
\hline $\begin{array}{l}\text { Talk to a parent or trusted adult and go to the nearest hos- } \\
\text { pital or health facility for a medical exam and treatment. }\end{array}$ & $\begin{array}{l}\text { Do not shower. Do not wash any clothes, including under- } \\
\text { wear. Talk to a parent or trusted adult. }\end{array}$ \\
\hline A doctor should confirm the assault. & Go to the nearest hospital or health facility for a medical \\
\hline $\begin{array}{l}\text { Take the medical report to the police station and collect a } \\
\text { P3 form. If severely hurt, the police should be asked to } \\
\text { visit the health facility with a P3 form to record the crime }\end{array}$ & $\begin{array}{l}\text { exam and treatment. A doctor should provide treatment, } \\
\text { confirm the rape, and obtain evidence. A PRC1 (Post Rape } \\
\text { Care) form should be completed in duplicate at this time. A }\end{array}$ \\
\hline $\begin{array}{l}\text { Have a P3 form filled and take it to the police doctor to } \\
\text { record the assault. (If up country, go to the District } \\
\text { Government Hospital.) }\end{array}$ & $\begin{array}{l}\text { PRC1 form allows the P3 form to be completed effectively } \\
\text { because it contains all clinical notes. You should be given } \\
\text { the original PRC1. }\end{array}$ \\
\hline $\begin{array}{l}\text { Take back the P3 form to the police station for the arrest } \\
\text { of the perpetrator (and keep a copy of the form for your- } \\
\text { self if possible). } \\
\text { Identify the accused for arrest. } \\
\text { Attend court when the accused is charged. }\end{array}$ & $\begin{array}{l}\text { Take the PRC1 to the police station where a report is entered } \\
\text { into the Occurrence Book. You will be issued a P3 form, } \\
\text { which should be free of charge. An OB number should be } \\
\text { given to you. Bring the clothes worn at the time wrapped in } \\
\text { newspaper (not nylon or plastic). If severely hurt, the police } \\
\text { should be asked to visit the health facility with a P3 form to } \\
\text { record the crime. }\end{array}$ \\
\hline & $\begin{array}{l}\text { The police record your statement and and that of any wit- } \\
\text { nesses. Sign it when you are satisfied with what is written. }\end{array}$ \\
\hline & $\begin{array}{l}\text { Take the P3 form to be completed by an authorized health } \\
\text { worker based on the PRC } 1 \text { form. (If up country, go to the } \\
\text { District Government Hospital.). The P3 form does not have } \\
\text { to be completed immediately. This can be done at a later } \\
\text { date after the medical evaluation is completed. }\end{array}$ \\
\hline & $\begin{array}{l}\text { Identify the accused for arrest and attend court when the } \\
\text { accused is charged. }\end{array}$ \\
\hline
\end{tabular}




\section{Tips for talking with special needs youth}

Encourage them to speak openly about their disability and to share any concerns they have about changes they are noticing in their bodies.

Present information in a simple and clear format. Be sure to use pictures to help explain the information (if appropriate).

Use repetition to help young people understand key information that is being shared. 


\section{Additional Resources}




\begin{tabular}{|c|c|c|c|}
\hline Method & Effectiveness & Advantages & Limitations \\
\hline $\begin{array}{l}\text { Abstinence: Do not engage in penetrative sex- } \\
\text { ual activity. To prevent pregnancy avoid vaginal } \\
\text { intercourse. To prevent STIs and HIV avoid } \\
\text { anal, vaginal and oral sex.Can engage in hand } \\
\text { holding, hugging, massaging, kissing, and } \\
\text { mutual masturbation. }\end{array}$ & $\begin{array}{l}100 \% \text { with con- } \\
\text { sistent use }\end{array}$ & $\begin{array}{l}\text { Most effective method } \\
\text { for preventing pregnan- } \\
\text { cy and STIs. Can be used } \\
\text { by those who have } \\
\text { already had sexual } \\
\text { intercourse (secondary } \\
\text { virginity). }\end{array}$ & $\begin{array}{l}\text { Requires high level of } \\
\text { motivation and self con- } \\
\text { trol. }\end{array}$ \\
\hline $\begin{array}{l}\text { Male condom: Fits over erect penis and pre- } \\
\text { vents sperm from entering vagina. Most are } \\
\text { made of latex rubber. Also known as socks, } \\
\text { gum boots, rubbers, raincoat, daddy's coat. }\end{array}$ & $\begin{array}{l}97 \% \text { with correct } \\
\text { and consistent } \\
\text { use; } 88 \% \text { with } \\
\text { normal use }\end{array}$ & $\begin{array}{l}\text { Easy to buy. Easy to use, } \\
\text { easy to carry. } \\
\text { Immediately effective. } \\
\text { Latex condoms are } \\
\text { highly protective } \\
\text { against HIV and } \\
\text { otherSTIs. }\end{array}$ & $\begin{array}{l}\text { Must be put on during } \\
\text { sex. Some men say it } \\
\text { reduces sexual feelings. } \\
\text { Condoms with spermi- } \\
\text { cide may irritate vagina } \\
\text { and penis. }\end{array}$ \\
\hline $\begin{array}{l}\text { Female condom: Made of thin, transparent soft } \\
\text { plastic and inserted into the vagina. }\end{array}$ & $\begin{array}{l}95 \% \text { with correct } \\
\text { and consistent } \\
\text { use; } 79 \% \text { with } \\
\text { normal use }\end{array}$ & $\begin{array}{l}\text { Immediately effective. } \\
\text { Woman controlled. Easy } \\
\text { to use with a little prac- } \\
\text { tice. Highly protective } \\
\text { against HIV and STIs. }\end{array}$ & $\begin{array}{l}\text { Requires insertion } \\
\text { before sexual inter- } \\
\text { course. Is expensive. }\end{array}$ \\
\hline $\begin{array}{l}\text { Spermicides: Immobilize and kills sperm. Not } \\
\text { recommended for use alone. Not recommended } \\
\text { for frequent use. }\end{array}$ & $\begin{array}{l}94 \% \text { with correct } \\
\text { and consistent } \\
\text { use; } 74 \% \text { with } \\
\text { normal use }\end{array}$ & $\begin{array}{l}\text { Effective immediately. } \\
\text { Women controlled. Easy } \\
\text { to use. Protects against } \\
\text { some STIs. }\end{array}$ & $\begin{array}{l}\text { Local irritation possible. } \\
\text { Does not protect against } \\
\text { HIV. }\end{array}$ \\
\hline $\begin{array}{l}\text { Diaphragm with spermicide: Small rubber cup } \\
\text { fits inside vagina, over the opening to the } \\
\text { womb. Used with contraceptive cream or jelly } \\
\text { that kills sperm. Must be fitted by clinician. }\end{array}$ & $\begin{array}{l}94 \% \text { with correct } \\
\text { and consistent } \\
\text { use; } 80 \% \text { with } \\
\text { normal use }\end{array}$ & $\begin{array}{l}\text { Woman controlled. Can } \\
\text { be put in } 2 \text { hours before } \\
\text { sex.May help protect } \\
\text { against STIs. }\end{array}$ & $\begin{array}{l}\text { Requires initial fitting. } \\
\text { More bladder infections } \\
\text { for some women.May be } \\
\text { hard to put in and take } \\
\text { out. Spermicide may irri- } \\
\text { tate vagina and penis. }\end{array}$ \\
\hline $\begin{array}{l}\text { Pills: Made of artificial hormones. Stop ovaries } \\
\text { from releasing an egg each month. Must be } \\
\text { prescribed by a clinician. }\end{array}$ & $\begin{array}{l}\text { More than } 99 \% \\
\text { with correct and } \\
\text { consistent use; } \\
97 \% \text { with normal } \\
\text { use }\end{array}$ & $\begin{array}{l}\text { Simple and easy to use. } \\
\text { Doesn't interfere with } \\
\text { sexLess bleeding and } \\
\text { cramping during period. } \\
\text { Protects against Pelvic } \\
\text { Inflammatory Disease, } \\
\text { ovarian and endometri- } \\
\text { al cancers. }\end{array}$ & $\begin{array}{l}\text { Small chance of blood } \\
\text { clots, heart attacks, } \\
\text { strokes and high blood } \\
\text { pressure. May have } \\
\text { weight changes, moodi- } \\
\text { ness, spotting, more } \\
\text { vaginal infections. Must } \\
\text { be taken every day. }\end{array}$ \\
\hline $\begin{array}{l}\text { Emergency contraceptive pills: Provide emer- } \\
\text { gency contraception when taken within } 5 \text { days } \\
\text { of unprotected sexual intercourse. Prevents } \\
\text { ovulation and inhibits transport of the egg } \\
\text { and/or sperm through the fallopian tubes. }\end{array}$ & $85 \%$ & $\begin{array}{l}\text { Provides emergency } \\
\text { contraception if used } \\
\text { within } 120 \text { hours after } \\
\text { unprotected sex. Can be } \\
\text { purchased over the } \\
\text { counter. }\end{array}$ & $\begin{array}{l}\text { May cause nausea vomit- } \\
\text { ing. Use with care with } \\
\text { women with cardiovas- } \\
\text { cular complications, } \\
\text { angina, migraines and } \\
\text { liver disease. Not meant } \\
\text { for repeated use. }\end{array}$ \\
\hline
\end{tabular}




\begin{tabular}{|c|c|c|c|}
\hline Method & Effectiveness & Advantages & Limitations \\
\hline $\begin{array}{l}\text { Injectables: Artificial hormones injected by a } \\
\text { clinician. Stop ovaries from releasing egg each } \\
\text { month. Thicken mucus so it's hard for sperm to } \\
\text { enter the womb. }\end{array}$ & More than $99 \%$ & $\begin{array}{l}\text { Does not interfere with } \\
\text { sex. Lasts } 3 \text { months. } \\
\text { Can be used while } \\
\text { breastfeeding. }\end{array}$ & $\begin{array}{l}\text { Should not be used by } \\
\text { women with liver dis- } \\
\text { ease, heart disease, } \\
\text { breast cancer, blood } \\
\text { clots. Irregular bleeding, } \\
\text { amenorrhoea and weight } \\
\text { gain may occur. May } \\
\text { affect bone development } \\
\text { in women under 18. May } \\
\text { be delay in getting preg- } \\
\text { nant after stopping use. }\end{array}$ \\
\hline $\begin{array}{l}\text { Implants: Tiny capsules of artificial hormones } \\
\text { put under skin of arm by a clinician. Capsules } \\
\text { slowly release hormones into bloodstream and } \\
\text { stop ovaries from releasing an egg each month. } \\
\text { Also, thickens mucus so it's hard for sperm to } \\
\text { enter the womb. }\end{array}$ & More than $99 \%$ & $\begin{array}{l}\text { Can stay in for } 5 \\
\text { years.Can be removed } \\
\text { anytime. Pregnancy } \\
\text { possible immediately } \\
\text { after removal. Always in } \\
\text { place. Does not inter- } \\
\text { fere with sex. }\end{array}$ & $\begin{array}{l}\text { For the first few months, } \\
\text { may have irregular peri- } \\
\text { ods. Beginning costs are } \\
\text { high. Minor surgery } \\
\text { required to insert or } \\
\text { remove. Should not be } \\
\text { used by women with } \\
\text { liver disease, heart dis- } \\
\text { ease, breast cancer or } \\
\text { blood clots. }\end{array}$ \\
\hline $\begin{array}{l}\text { IUCD (Intrauterine Contraceptive Device): } \\
\text { Small device put inside womb by a trained serv- } \\
\text { ice provider. Stops sperm from joining egg or } \\
\text { fertilized egg from implanting and growing in } \\
\text { womb. }\end{array}$ & $97-99 \%$ & $\begin{array}{l}\text { Always in place. Does } \\
\text { not interfere with sex. }\end{array}$ & $\begin{array}{l}\text { Increased chance of } \\
\text { tubal infection (which } \\
\text { may lead to sterility) for } \\
\text { women with more than } \\
\text { one partner or whose } \\
\text { partner has other part- } \\
\text { ners. Can puncture } \\
\text { womb. May have more } \\
\text { bleeding and cramping } \\
\text { during period or spot- } \\
\text { ting between periods. }\end{array}$ \\
\hline $\begin{array}{l}\text { Lactational amenorrhea method (LAM): } \\
\text { Temporary method for the } 6 \text { months following } \\
\text { childbirth, for women who are not menstruat- } \\
\text { ing and are fully or nearly fully breastfeeding. }\end{array}$ & $\begin{array}{l}98 \% \text { during } 6 \\
\text { months after } \\
\text { childbirth, if } \\
\text { used correctly }\end{array}$ & $\begin{array}{l}\text { No cost. No side effects. } \\
\text { Provides proper nutri- } \\
\text { tion for baby. }\end{array}$ & It is temporary. \\
\hline $\begin{array}{l}\text { Natural family planning: Methods to deter- } \\
\text { mine when woman can and cannot get preg- } \\
\text { nant (includes charting temperature, vaginal } \\
\text { mucus, menstrual bleeding); can abstain from } \\
\text { sex or use contraceptives during fertile time. }\end{array}$ & $\begin{array}{l}91-97 \% \text { with cor- } \\
\text { rect and consis- } \\
\text { tent use. } 80 \% \\
\text { with normal use. }\end{array}$ & $\begin{array}{l}\text { Improved knowledge of } \\
\text { reproductive system. No } \\
\text { cost. No devices or } \\
\text { chemicals. }\end{array}$ & $\begin{array}{l}\text { Need cooperation of the } \\
\text { couple. Requires daily } \\
\text { record keeping and } \\
\text { training. Requires peri- } \\
\text { ods of abstinence or use } \\
\text { of other methods. } \\
\text { Cannot use with irregu- } \\
\text { lar periods or tempera- } \\
\text { ture patterns. }\end{array}$ \\
\hline $\begin{array}{l}\text { Withdrawal: Man interrupts intercourse and } \\
\text { withdraws his penis from his partner's vagina } \\
\text { before he ejaculates. }\end{array}$ & $81 \%$ & $\begin{array}{l}\text { No cost. Is a back-up } \\
\text { contraceptive that is } \\
\text { always available. }\end{array}$ & Difficult to practice. \\
\hline $\begin{array}{l}\text { Sterilization: } 0 \text { peration that makes a person } \\
\text { unable to have a baby. Both men and women } \\
\text { can be sterilized. }\end{array}$ & $99.6 \%$ & $\begin{array}{l}\text { No other method will } \\
\text { ever be needed. No } \\
\text { physical effect on sexu- } \\
\text { al desire or ability. }\end{array}$ & $\begin{array}{l}\text { Permanent. Small risk of } \\
\text { infection or bleeding } \\
\text { after surgery. Chance of } \\
\text { tubal pregnancy. }\end{array}$ \\
\hline
\end{tabular}




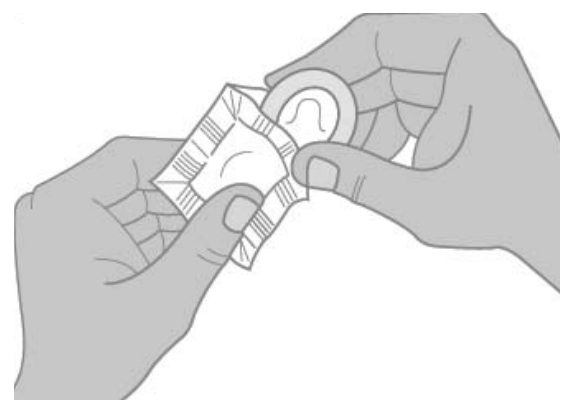

1. Open the packet carefully. Do not use anything sharp like a knife or nails. Ensure that the part to be unrolled is on the outside.

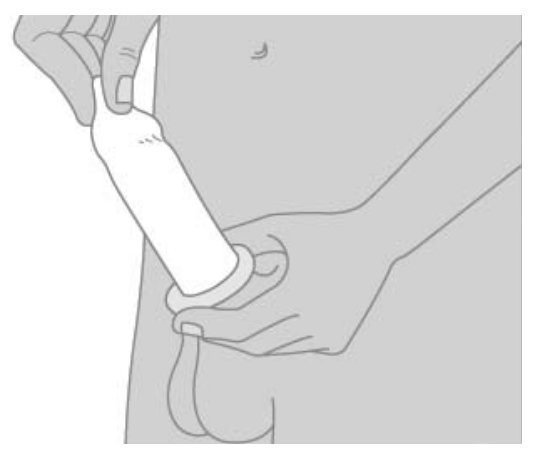

3. Unroll the condom all the way to the base of the penis.

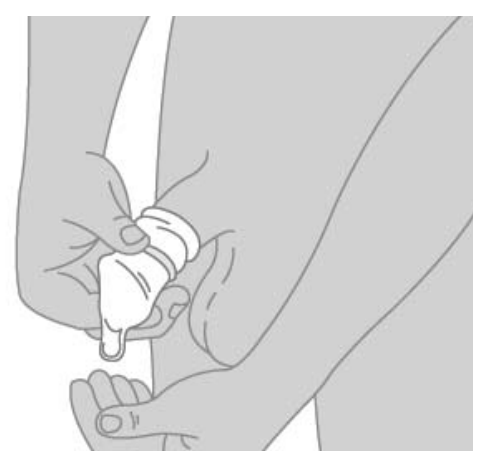

5. While still holding the base, pull off the condom gently so as not to spill the contents.

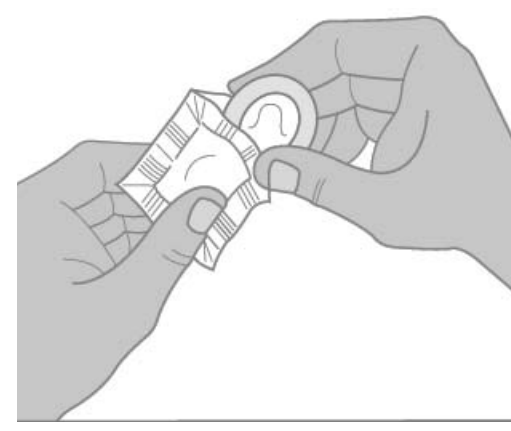

2. Pinch the tip of the condom. Place it on the hard penis.

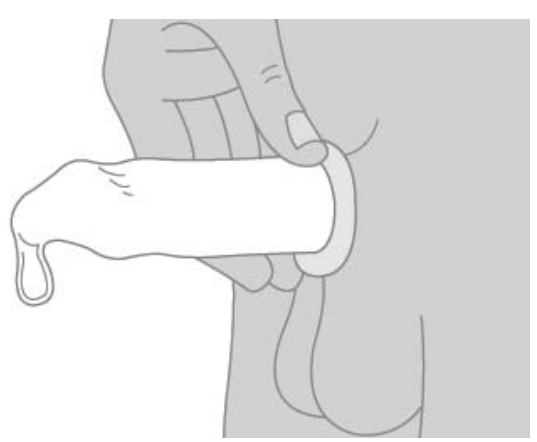

4. After ejaculation, hold the condom at the base of the penis so it does not slip off.

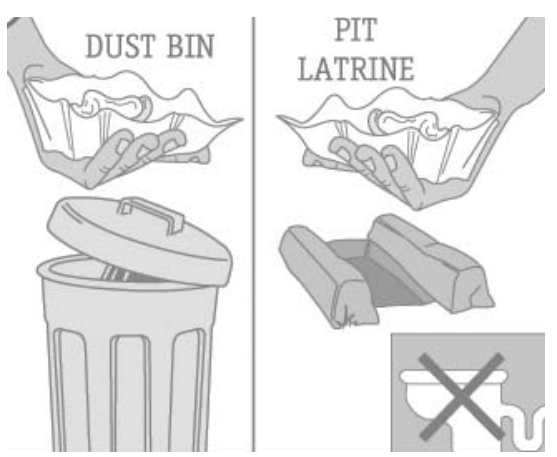

6. Wrap condom in tissue paper and throw it away in a latrine or somewhere out of reach of children. Never flush a condom down the toilet. 


\section{Resource 3: How to Use a Female Condom}

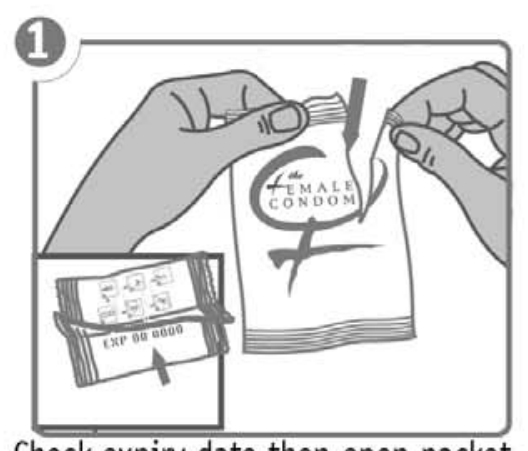

Check expiry date then open packet. Do not use sharp objects or teeth.
2

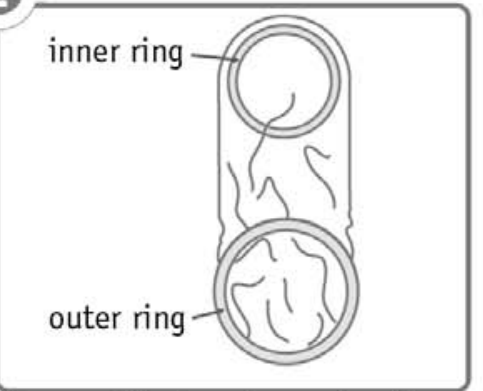

Remove the female condom from the packet. Rub the condom to spread the jelly.
3

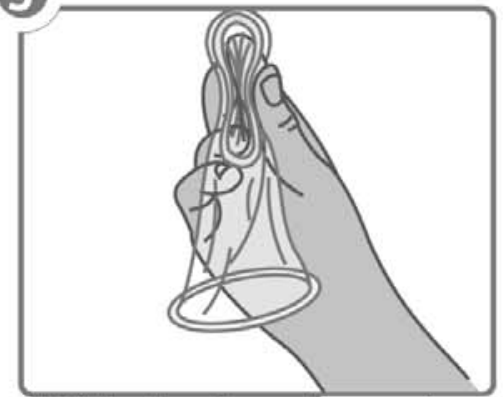

Hold the female condom as shown above, making the inner ring long and narrow.

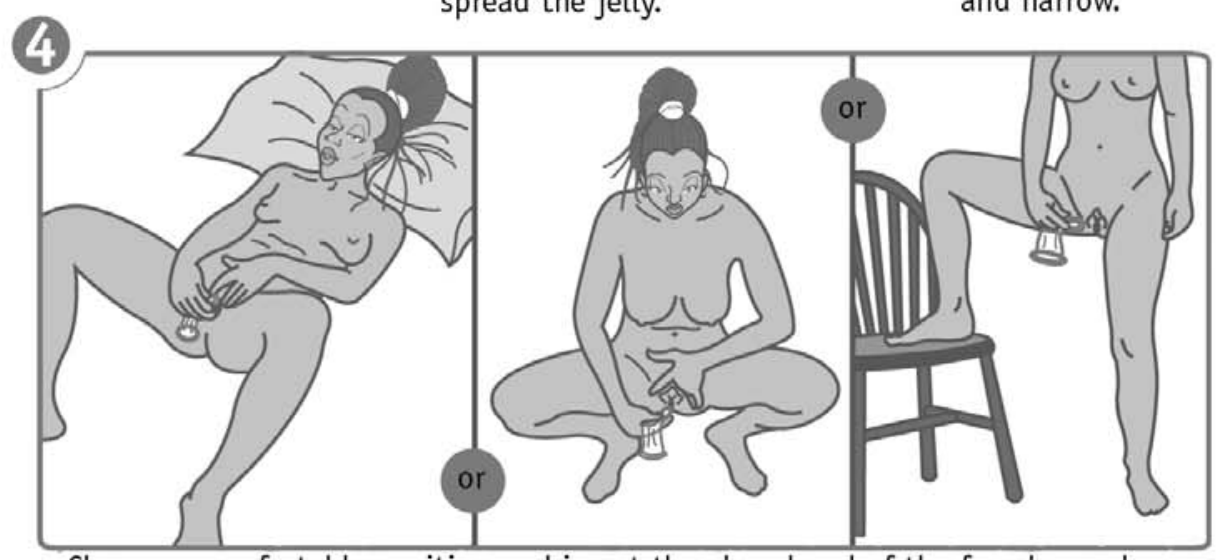

Choose a comfortable position and insert the closed end of the female condom into the vagina.

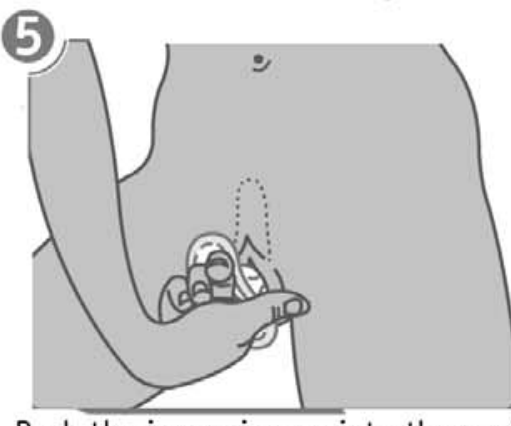

Push the inner ring up into the vagina as far as it will go. Do not twist it.
6

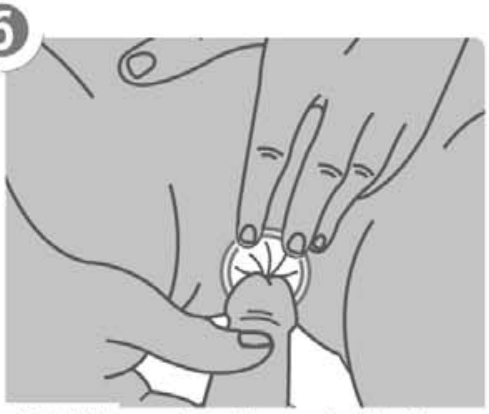

Hold the outer ring outside the vagina and guide penis into female condom.

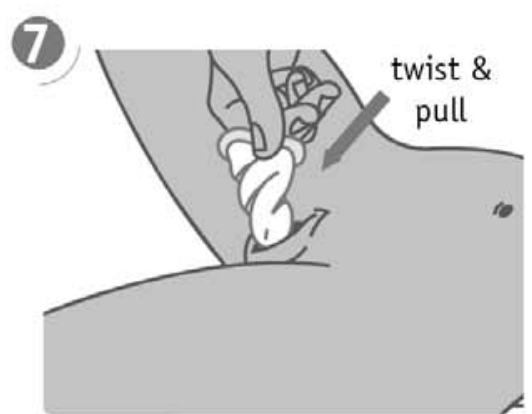

Immediately after intercourse, twist the outer ring to avoid spillage and gently pull condom.

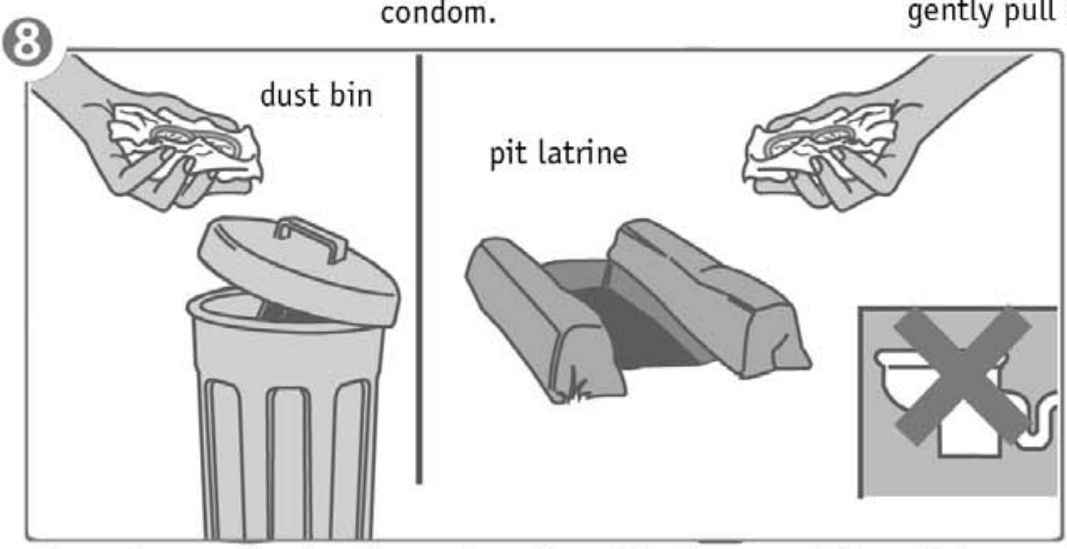

Do not re-use the female condom. Wrap it in tissue and throw it in a dust bin or pit latrine. Never throw it in a flush toilet. 


\section{Accommodating Youth with Special Needs}

Adolescents with physical or intellectual disabilities need sexuality education just as much as any other young people. Some may need more patience, repetition of information and time to understand the information presented to them.

The sexual development of special needs youth is often overlooked under the assumption that young people who have disabilities are not able to or should not be allowed to engage in loving, sexual relationships. It is important, however, to give special attention to these young people in order to provide them with correct and easyto-understand information so that they can make the best choices when faced with decisions about sexuality.

Sexuality education for special needs youth should be tailored to each individual with particular attention to his or her disability. This is a decision that should be made with involvement from parents or guardians. It is important to encourage an open discussion in order for parents and young people to feel comfortable talking.

Some factors to consider when providing sexual education to young people with disabilities include:

How the adolescent's disability may affect his or her sexuality and sexual development. Young people with disabilities may go through puberty much later or much earlier than their peers or may experience different changes during puberty.

How the adolescent's disability may affect his or her ability to understand sexual and reproductive health education. For example, some young people with disabilities may perform better with different types of learning materials, such as lower-literacy or large print materials.

Any additional information that may be needed to address the specific disability of the individual adolescent with regard to his or her development. For example, some disabilities could prevent young people from becoming pregnant.

Sexuality education for young people with special needs should cover anatomy and reproductive physiology, changes during puberty, information about sexually transmitted infections, and knowledge about the correct ways to prevent pregnancy and STIs, including HIV. Life skills, such as decision-making, self-esteem, negotiation skills and setting goals should also be incorporated into any sexuality education programme for special needs youth.

\section{References}

African Medical and Research Foundation (AMREF). Parents of Tomorrow: A Guide to Adolescent Sexual and Reproductive Health, AMREF; 1996.

CEDPA. Choose a Future! Issues and Options for Adolescent Girls. A Sourcebook of Participatory Learning Activities. Washington, DC: CEDPA; 1996.

Central Bureau of Statistics (CBS) [Kenya], Ministry of Health (MOH) [Kenya], and ORC Macro. Kenya Demographic and Health Survey 2003. Calverton, Maryland: CBS, MOH, and ORC Macro; 2004.

Division of Reproductive Health, Ministry of Health ( $\mathrm{MOH})$, Government of Kenya. National guidelines for provision of youth friendly services in Kenya. Nairobi: $\mathrm{MOH} ; 2005$ [in press].

Division of Reproductive Health, Ministry of Health (MOH), Government of Kenya. National guidelines: Medical Management of Rape and Sexual Violence. Nairobi:MOH; 2004.

EngenderHealth. Youth Friendly Services: A Manual for Service Providers [Draft]. New York:Engender Health; 2002.

Family Health International. Meeting the Needs of Young Clients. A Guide to Providing RH Services to Young Adolescents. 2000.

National Center for HIV, STD and TB Prevention, Divisions of HIV/AIDS Prevention, Centers for Disease Control and Prevention's Frequently Asked Questions on HIV and AIDS website. Available at: 
http://www.cdc.gov/hiv/pubs/faqs.htm

Parenting South Australia. Talking Sex with Teens. Parent Easy Guide 68. Parenting South Australia and Child and Youth Health. 2003.

PATH. Life Planning Skills: A Curriculum for Young People in Africa, Ghana Version. Facilitator's Manual. Washington, D.C.: PATH; 2003.

PATH. Life Planning Skills: A Curriculum for Young People in Africa, Ghana Version. Facilitator's Manual. Nairobi: PATH; 1996.

PATH, Population Council. Tuko Pamoja: Adolescent Reproductive Health and Life Skills Curriculum. Nairobi: PATH; 2005.

Regional Centre for Quality of Health Care (RCQHC). Flyer Good for You! [flyer] Kampala, Uganda: RCQHC, Makerere University; 2004.

Senderowitz J, Solter C, Hainsworth G. Module 16: Reproductive Health Services for Adolescents - Participant's Manual. Comprehensive Reproductive Health and Family Planning Training Curriculum. Watertown, Massachusetts: Pathfinder International; 2002.

Senderowitz J. Making Reproductive Health Services Youth Friendly. Research, Program and Policy Series. Washington, DC: FOCUS on Young Adults; 1999.

van Vuuren L, R Davis, V Denman, D Dortzbach, M Elmer, E Vor der Bruegge. Facing AIDS Together: HIV/AIDS Prevention and Care- Facilitator Guide. Baltimore, Maryland: World Relief and Freedom from Hunger; 2002. WH0. Orientation Programme on Adolescent Health for Health-care Providers. Geneva: WH0; 2003. 